\title{
Review
}

\section{A Comprehensive Review of Tic Disorders in Children}

\author{
Keisuke Ueda ${ }^{1, *(\mathbb{D})}$ and Kevin J. Black 1,2,3,4 (D) \\ 1 Department of Neurology, Washington University School of Medicine, St. Louis, MO 63110, USA; \\ kevin@wustl.edu \\ 2 Department of Psychiatry, Washington University School of Medicine, St. Louis, MO 63110, USA \\ 3 Department of Radiology, Washington University School of Medicine, St. Louis, MO 63110, USA \\ 4 Department of Neuroscience, Washington University School of Medicine, St. Louis, MO 63110, USA \\ * Correspondence: k.ueda@wustl.edu; Tel.: +1-314-454-6120
}

check for

updates

Citation: Ueda, K.; Black, K.J. A Comprehensive Review of Tic Disorders in Children. J. Clin. Med. 2021, 10, 2479. https://doi.org/ $10.3390 /$ jcm10112479

Academic Editor: Giuseppe Lanza

Received: 8 April 2021

Accepted: 31 May 2021

Published: 3 June 2021

Publisher's Note: MDPI stays neutral with regard to jurisdictional claims in published maps and institutional affiliations.

Copyright: (c) 2021 by the authors. Licensee MDPI, Basel, Switzerland. This article is an open access article distributed under the terms and conditions of the Creative Commons Attribution (CC BY) license (https:/ / creativecommons.org/licenses/by/ $4.0 /)$.

\begin{abstract}
Tics are characterized by sudden, rapid, recurrent, nonrhythmic movement or vocalization, and are the most common movement disorders in children. Their onset is usually in childhood and tics often will diminish within one year. However, some of the tics can persist and cause various problems such as social embarrassment, physical discomfort, or emotional impairments, which could interfere with daily activities and school performance. Furthermore, tic disorders are frequently associated with comorbid neuropsychiatric symptoms, which can become more problematic than tic symptoms. Unfortunately, misunderstanding and misconceptions of tic disorders still exist among the general population. Understanding tic disorders and their comorbidities is important to deliver appropriate care to patients with tics. Several studies have been conducted to elucidate the clinical course, epidemiology, and pathophysiology of tics, but they are still not well understood. This article aims to provide an overview about tics and tic disorders, and recent findings on tic disorders including history, definition, diagnosis, epidemiology, etiology, diagnostic approach, comorbidities, treatment and management, and differential diagnosis.
\end{abstract}

Keywords: tics; Tourette syndrome; natural course; differential diagnosis; pediatric movement disorder; premonitory urge; comorbid symptoms

\section{Introduction}

Movement disorders are central nervous system disorders that cause abnormal, unwanted movements and are usually unrelated to weakness or spasticity. Dysfunction of the basal ganglia and frontal cortex plays an important role in most movement disorders in children [1]. Conventionally, movement disorders are divided into two categories. The first category is hyperkinetic movement disorders, associated with an excess of movement (e.g., excessive, unnatural, and involuntary movement). These include tics, stereotypies, chorea, myoclonus, dystonia, and tremor [2]. The second group is hypokinetic movement disorders, with a paucity of movement (e.g., decreased amplitude, decreased speed, or loss of movement), including bradykinesia, akinesia, and rigidity [2]. Unlike hypokinetic movement disorders, hyperkinetic movement disorders, especially tic disorders, are relatively common in the pediatric population.

The most common movement disorders in the pediatric population are tic disorders, including Tourette syndrome (TS). In 1825, Jean-Marc Gaspard Itard reported the case of a French noblewoman who exhibited involuntary body movements involving the shoulders, neck, and face, and vocalization such as making barking sounds and uttering obscene language [3]. Subsequently, George Gilles de la Tourette referred to this case and reported nine patients with tic disorders [2]. Notably, these reports described the essential clinical features of tic disorders, such as early onset, waxing and waning course, echolalia, coprolalia, and echopraxia. For some time, a tic was regarded as a symptom of functional disorders like hysteria, neurosis, or narcissism. In 1968, the first case was reported of a patient whose 
tics improved with neuroleptics [4]. Since then, tic disorders have been discussed primarily in a neurobiological context. They are frequently accompanied by psychiatric comorbidities such as attention-deficit hyperactivity disorder (ADHD), obsessive-compulsive disorder (OCD), anxiety, and depression. Optimal treatment of tic disorders therefore requires a multidisciplinary approach involving neurologists, psychiatrists, psychologists, and behavioral therapists.

\section{Definition}

Tics are defined as "sudden, rapid, recurrent, nonrhythmic motor movement (motor tics) or vocalization (vocal or phonic tics)" [5]. Both motor and vocal tics are classified as simple or complex, although differentiating a simple tic from a complex tic is not always straightforward. Simple motor tics are brief, abrupt, repetitive, and seemingly non-purposeful movements, and involve only one muscle group or body part (e.g., face, neck, shoulders, or hands) [6]. Motor tics most frequently involve the eyes and mouth, followed by the neck and limbs; feet and midline axial structures are the least frequently involved [7,8]. Examples of motor tics include blinking, eye rolling, wide opening of the eyes or mouth, tilting the neck, raising the shoulders, and shaking the hands. Based on their phenomenology, simple motor tics are subdivided into three groups: clonic, dystonic, and tonic tics [9]. Clonic tics are abrupt, rapid, brief jerking movements (e.g., blinking, facial grimacing, head jerking). Dystonic tics are slower, resulting in briefly sustained abnormal postures (e.g., a prolonged involuntary upward deviation of the eyes, eye closure, bruxism, mouth opening, or torticollis). Tonic tics are isometric contractions (e.g., tensing of abdominal and limb muscles) [9-11]. Some tics may result in the transient interruption of ongoing motor activities or speech without loss of consciousness. Such tics are often referred to as blocking tics [12]. By contrast, complex motor tics are caused by several muscle groups and sometimes appear to be purposeful, coordinated, or orchestrated patterns of movement. Examples include touching, tapping, waving, kicking, jumping, echopraxia (mimicking others' gestures), and copropraxia (performing obscene or forbidden gestures or inappropriate touching).

Simple vocal tics are meaningless sounds made by moving air through the nose, mouth, or throat. Vocal tics are often referred to as "phonic tics," because the sound may be produced not only by contraction of the vocal cords but also by contraction of the nasal, oral, laryngeal, pharyngeal, and respiratory muscles. Examples include coughing, throat clearing, grunting, mimicking animal noises, and tongue clicking. Complex vocal tics involve several muscle groups and are characterized by words, phrases, or sentences. Examples include shouting and yelling, echolalia (repeating another person's words), and coprolalia (uttering socially inappropriate expressions). Coprolalia is seen in $8-17 \%$ of patients with TS, and its onset is usually around the age of 15 years [13-15].

The Diagnostic and Statistical Manual of Mental Disorders, 5th edition (DSM-5), defines five tic disorders: Provisional Tic Disorder, Persistent (chronic) Motor or Vocal Tic Disorder, Tourette's Disorder (also known as Tourette syndrome), Other Specified Tic Disorder, and Unspecified Tic Disorder [5]. The first three tic disorders require that the onset be before age 18 years and the symptoms not be caused by other medical illnesses such as Huntington's disease, substance abuse, or medication side effects. Provisional Tic Disorder is considered when tics (motor or vocal or both) have been present for less than one year since tic onset. Both TS and Persistent (chronic) Motor or Vocal Tic Disorder indicate the presence of tics for longer than one year (though intervening tic-free periods are allowed). Persistent (chronic) Motor or Vocal Tic Disorder is diagnosed when individuals have exhibited either motor or vocal tics (but not both) at some time during the illness. When both motor and vocal tics have occurred during the course of the disease, though not necessarily concurrently, TS is diagnosed. Patients with TS tend to have a higher severity of tics, greater prevalence of complex motor tics (e.g., copropraxia and echopraxia), and more comorbid symptoms than patients with Persistent Motor Tic Disorder [16]. 
The final two tic disorders are new categories in the DSM-5. In the DSM-IV, tic disorders that did not meet the criteria for specific tic disorders were categorized as Tic Disorder Not Otherwise Specified. Instead of this category, the DSM-5 uses Other Specified Tic Disorder and Unspecified Tic Disorder when tic symptoms cause clinical distress or impairment, but the individual does not meet the criteria for the first three tic disorders. For example, Other Specified Tic Disorder is used when clinicians choose to describe the specific reason for not meeting the criteria (e.g., onset after 18 years), whereas Unspecified Tic Disorder is used when clinicians choose not to specify the reason why the criteria are not met (e.g., lack of sufficient information to make a more specific diagnosis). Importantly, the diagnostic criteria of tic disorders do not mention tic severity.

Under the DSM-IV, a diagnosis of Transient Tic Disorder required tics lasting for at least four weeks, and Persistent Tic Disorder and TS required a year of tics without a tic-free period of more than three consecutive months. These criteria were removed from the DSM-5. There was no factual basis for the four-week limit and most tic symptoms last longer than four weeks. The criterion of "three consecutive months" was not supported by epidemiological studies [17]. Furthermore, "Transient" Tic Disorder was changed to "Provisional" Tic Disorder in the DSM-5 due to confusion about the meaning of "transient" [Appendix 1 in ref. [18]]. Although some motor tics are stereotyped, the word "stereotyped" is no longer used in the definitions of tic disorders to avoid confusion between tics and Stereotypic Movement Disorder. In the DSM-IV, tic disorders had to cause clinically significant impairment or distress to patients, but this criterion was removed beginning with DSM-IV-TR. Tic symptoms do not always cause such impairment. Indeed, many children with tics are not always bothered by their tics, but rather by other neuropsychiatric comorbidities [19].

\section{Clinical Course}

In clinical practice, the diagnosis of tics is usually straightforward and can be made by reference to the patient's clinical history. Although a complete physical examination with direct clinical observation is important in diagnosing neurological disorders, the neurological examination is normal in children with a tic disorder, except for the tics themselves [20]. Interestingly, patients with tics may subconsciously suppress their tics in the clinic [21]. In that case, it is wise to ask their guardians to video record their tics at home to understand their characteristics and severity. Diagnosis does not require laboratory testing or neurological imaging studies.

Understanding the natural course of tics is therefore essential. Tics usually begin between 3 and 8 years of age. The first tic symptoms are usually simple motor tics involving the face, head, or neck. Tics then spread in the rostro-caudal direction over time [22]. The first vocal tics occur on average a few years after the onset of motor tics and are usually simple vocal tics such as throat clearing or sniffing [22]. Conventionally, most tics are believed to go away on their own within a few months. However, epidemiological data for the clinical course of the new onset of tics are sparse. Conducting a follow-up study of Provisional Tic Disorder is difficult, as many patients do not seek medical help for their tics unless they find them bothersome [23]. A clinical follow-up study of children with recent onset of tics (less than six months since the first tic) showed that their tics persisted 12 months after the new onset, but most of the children were no longer bothered by their tics [24]. One explanation for this discrepancy is related to the benign nature of tic disorders. If tics are minimal or mild and do not cause any impairment or distress, patients and family members may not recognize them or feel it necessary to seek medical attention. If patients do not return to the clinic, this may be misinterpreted as remission of the tics.

If tics persist for more than one year, the severity usually peaks around 8-12 years of age [22]. Most patients with tics experience significant improvement or complete resolution by early adulthood [25]. Although tics are still present on direct examination in $88-100 \%$ of adults with a TS diagnosis in childhood or adolescence [26], about 33-47\% of patients with TS report being completely tic free, less than $50 \%$ have mild tics, and less than $25 \%$ have 
moderate or severe tics in adulthood [22,25-27]. In other words, most patients with TS are no longer bothered by tics in adulthood. This fact can be welcome information for patients and guardians who are anxious about the prognosis of tic disorders [28].

Tics usually follow a waxing and waning pattern in severity and frequency, with a mixture of old and new tics. Although the onset of TS does not seem to be associated with life events, exacerbations and fluctuating severity of tics are related to environmental factors [29]. Tics may be temporarily exacerbated by psychological strains (e.g., stress, anxiety, excitement, anger), physical strains (e.g., fatigue, sleep deprivation, and infections), and environmental changes. This exacerbation is usually transient and subsides after the cause resolves. Individuals with tics often experience an unpleasant sensation preceding the tics, referred to as a premonitory urge, which is temporarily relieved by the execution of the tics [30-32]. Over $90 \%$ of adolescents and adults with TS [33-35] and 37\% of children with TS from age 8 to 19 years [36] reportedly experience premonitory urges to some extent. Unlike other movement disorders, tics may be voluntarily suppressed for variable periods, which is known as tic suppressibility $[11,37,38]$.

Various studies including genetic studies, neuropsychological testing studies, and neuroimaging studies have revealed only a few predictive factors of future tic disorders [28]. A clinical interview study of adults who had tics in childhood showed that tic severity in childhood and the presence of coprolalia were not necessarily predictors of adulthood tic severity [39]. In contrast, another clinical prospective longitudinal study of adults who had tics in childhood showed that severity of tics in late childhood was associated with tic severity in early adulthood [28]. Comorbid symptoms such as ADHD, OCD, and depression persist into adulthood and require close monitoring $[40,41]$.

\section{Epidemiology}

It is difficult to estimate the true prevalence of tic disorders because a significant number of people do not recognize their tics or do not seek medical care [42,43]. The reported prevalence of tics in children therefore varies considerably [44-46]. Tics are more likely to affect boys than girls by a ratio of 1.5-4:1 [44,47,48]. The incidence of motor tics is higher in the winter months than in the spring months [47]. In a direct observational study where the researchers went to local schools to rate children's tics, at least one motor tic was noted in $47 \%$ of 1st-grade students and $15 \%$ of 6th-grade students, and the overall cross-sectional prevalence of tics during childhood was approximately $19-24 \%[18,47,49]$. Other observational studies using questionnaires revealed that tics were found in $22 \%$ of preschool children, $7.8 \%$ of elementary school children, and $3.4 \%$ of adolescents [50]. A similar tendency has been observed in other countries. For example, in Poland, the overall lifetime prevalence of tics is $9.9 \%$ (12\% for boys and $7.7 \%$ for girls) [48]. In Spain, tics were noted in about $17 \%$ of school-aged students ( $19 \%$ for boys and $13 \%$ for girls) [51]. The prevalence of tics in children receiving special education was estimated to be $20-23 \%$, with $5.3-7.0 \%$ of them meeting the criteria for TS $[49,51]$.

The prevalence of TS is estimated at around $0.4-3 \%$ in regular school students [52-55]. Furthermore, the prevalence of TS in children with autistic spectrum disorder is higher: $22 \%$ of children with autistic spectrum disorder were found to have chronic motor tics and $11 \%$ were diagnosed with TS [56].

Tic disorders are the most common movement disorders in the pediatric population, but adult-onset primary tic disorder is rare [26,57] and is usually associated with underlying neuropsychiatric disorders (e.g., Down syndrome, Huntington's disease, neuroacanthocytosis) [58,59], head or peripheral trauma [60-62], basal ganglia stroke [63], HIV infection [64], and neuroleptic and antiepileptic side effects or cocaine abuse [65-69]. Indeed, many adult tics are reoccurrences or continuations of childhood tics [39,70].

\section{Etiology}

The pathophysiology of tic disorders involves impaired function of cortical-striatalthalamic-cortical circuits with aberrant associated neurotransmitter function, including 
dopamine, serotonin, and gamma-aminobutyric acid (GABA), and development-related atypical functional brain connectivity [31,71-77]. The etiology of tic disorders is complicated and multifactorial, including polygenic factors and non-genetic factors such as environmental factors and immune-mediated mechanisms, contributing to the heterogeneous clinical phenotype [78].

\subsection{Environmental Factors}

The specific environmental factors influencing the development of tic disorders have remained elusive. Various studies have investigated prenatal and perinatal epigenetic factors. A direct interview study found a correlation of tics with maternal life stress during pregnancy and nausea and vomiting during the first trimester of pregnancy [79]; a retrospective review study found a correlation with early prenatal care in the first trimester, more prenatal visits, decrease in the Apgar score at five minutes, and the month when prenatal care began [80]; and a systematic review found a correlation with low birth weight and prenatal maternal smoking [81,82]. However, a prospective, population-based, pre-birth cohort study identified alcohol use during pregnancy, cannabis use during pregnancy, and parity and inadequate weight gain during pregnancy as prenatal risk factors for chronic tic disorder, but other risk factors such as prenatal maternal smoking, gestational age, low birth weight, and complications of delivery were not associated with tic disorders [83].

In a case-control study [84], parental psychiatric disorders (especially in mothers) were associated with a greater likelihood of children developing TS and chronic tic disorders. A questionnaire survey showed that children from nuclear families with poor parental relationships were at more risk of developing TS [85]. However, the onset of tics was not associated with stressful life events [29].

\subsection{Genetic Factors}

In 1885, Georges Gilles de la Tourette pointed out possible genetic factors of tic disorders [86]. Since then, numerous studies have investigated genetic factors in tic disorders. Segregation analyses of 27 families with TS patients demonstrated autosomal dominant transmission patterns [87]. A twin study with probable monozygotic (MZ) and dizygotic (DZ) twins showed that concordance rates for tics were $77 \%$ and $23 \%$ for $\mathrm{MZ}$ and DZ pairs, respectively, and those for TS were $53 \%$ and $8 \%$ for MZ and DZ pairs, respectively [88]. A subsequent study with MZ twins also showed high concordance rates of $94 \%$ for tic disorders and $56 \%$ for TS, which indicates a genetic etiology with high penetrance [89].

Currently, tic disorders and TS are considered to be polygenic inherited disorders involving a large number of different genes. In a population-based cohort study using the Genome-wide Complex Trait Analysis program, the heritability of TS was estimated as 0.58$0.77[90,91]$. The same population-based study also revealed that the risk of developing tic disorders for first-degree relatives of probands with tic disorders was significantly higher than that for second and third-degree relatives [91]. Full siblings of individuals with tic disorders have a significantly higher risk of developing tic disorders than maternal halfsiblings, regardless of similar environmental exposure, suggesting that the environment is much less important in causing tic disorders [91].

Several candidate susceptibility genes for TS have been suggested but have not been confirmed yet, probably because of the small sample size of each study and genetic and phenotypic heterogeneity [92]. A family with TS had an insertion or translocation of chromosomes 2 and 7 disrupting the CNTNAP2 gene on chromosome 7q35-q36, probably leading to disturbed distribution in potassium channels in the nervous system [93]. Another case report of a family with TS showed that a deletion of exons 4, 5, and 6 of the NLGN4 gene on chromosome Xp22.32-p22.31 was associated with TS and neuropsychiatric disorders such as autistic spectrum disorder, ADHD, learning disorders, anxiety, and depression [94]. The SLITRK1 gene on chromosome 13q31.1, which encodes a single-pass transmembrane protein in the central nervous system, may be associated with TS as well 
as obsessive-compulsive disorders and schizophrenia [95,96]. The HDC gene on chromosome 15q21.2 encodes L-histidine decarboxylase that plays a role in histidine metabolism. A mutation in the HDC gene may be implicated in tics and TS by affecting histaminergic neurotransmission [97]. The IMMP2L gene on chromosome 7q31.1 encoding the inner mitochondrial membrane peptidase subunit 2 has also been implicated in TS $[98,99]$. In an animal study, the Immp $2 l$ mutation caused excessive mitochondrial superoxide generation and an increase in cellular oxidative stress [100]. However, a recent study using skin fibroblasts from patients with TS with the IMMP2L deletions revealed no evidence of substantial mitochondrial dysfunction in GTS fibroblasts [101].

A genome-wide screening of single nucleotide polymorphism (SNP) genotyping microarray with patients with TS showed 5 exon-affecting rare copy number variants involving the NRXN1, AADAC, CTNNA3, FSCB, KCHE1-KCHE2-RCAN1 genes [102]. An analysis of a European ancestry sample of TS cases for rare ( $<1 \%$ frequency) copy number variants using SNP microarray data demonstrated that the NRXN1 deletions and CNTN6 duplications were associated with a substantially increased risk of developing TS [103]. Whole-exome sequencing studies identified the CELSR3 gene on chromosome 3 p21.31 [104] and the ASH1L gene on chromosome 1q22 [105] as high-risk genes for TS. Exome sequencing in patients with TS revealed possibly disrupting variants of the OPRK1 gene on chromosome 8q11.23, encoding the opioid kappa receptor [106]. The Brainstorm Consortium genome-wide association studies (GWAS) of TS have indicated an association between TS and the COL27A1 gene on chromosome 9q32-33 [107,108]. These results converge to the conclusion that tic disorders are not single-gene disorders, but genetic predisposition with environmental factors might increase the risk of developing tic disorders. Further studies are necessary to establish biological correlates of these genes and tic disorders.

\subsection{Immunologic Factors}

Abnormal immune responses have been proposed as underlying causes of tics, and such proposals have prompted investigation with different approaches, including animal studies, post-mortem studies, and laboratory studies. These studies have revealed some evidence for immune-mediated mechanisms, including impaired activation of the innate immune response, especially to bacterial infection [109]; elevation of interleukin-12 and tumor necrosis factor at baseline [110]; deficit in T-cell regulation [111]; increased titers of adhesion molecules as markers of a systemic inflammatory response [112]; altered immunoglobulin profile [113]; presence of oligoclonal bands in central spinal fluid [114-116]; microglial involvement; over-activity of systemic immune responses; and dysfunctional neural-immune crosstalk [117].

Some cases of TS may represent a central nervous system autoimmune disorder following infection. In 1978, a case was reported of an 11-year-old boy who developed severe tic symptoms after a febrile streptococcal infection, evidenced by elevated anti-streptolysin $\mathrm{O}$ (ASO) titers [118]. The patient did not respond to haloperidol but responded dramatically to prednisolone. In 1992, it was reported that two children developed tic symptoms after a streptococcal infection and also did not respond to neuroleptics but reached complete remission with adrenocorticotropic hormone and prednisone [119]. A clinical study of children with recent onset of movement disorders (tics and chorea) found that children with these movement disorders were more likely than those without to be positive for an anti-neuronal antibody directed against caudate nuclei and had elevated ASO titers than children without the movement disorders [120]. Subsequent case-control studies of patients with TS showed a significant increase in streptococcal antibodies such as ASO and anti-basal ganglia antibodies [121], and antibodies against putamen, but not the caudate or globus pallidus [122]. A large case-control study of 150 children with tic disorders demonstrated a significant elevation of ASO titers in children with tics compared to those of controls and a positive correlation between ASO titers and tic severity [123]. A crosssectional study comparing children and adults with TS to children with other neurological 
diseases, children with recent uncomplicated streptococcal infections, adults with neurological disease, and healthy adults revealed a significant elevation of ASO titers in both children and adults with TS [124]. The most common basal ganglia binding antigen was similar to the proposed antigen in Sydenham's chorea [124]. Thus, an autoimmune process caused by the cross-reacting of streptococcal bacterial antigens to the brain anti-neuronal antibodies, similar to the process of Sydenham's chorea, was suggested as a pathophysiological mechanism of TS.

Pediatric autoimmune neuropsychiatric disorders associated with streptococcal infections (PANDAS) has been hypothesized as a subset of children with acute onset of tics or OCD following streptococcal infection. The diagnostic criteria include the following: (1) the presence of either OCD or tic disorder or both; (2) onset before puberty (usually between 3 and 12 years of age); (3) abrupt, dramatic, and explosive onset and/or episodic course; (4) a relapsing and remitting clinical course of symptoms with temporal relation associated with streptococcus infection; and (5) other neurological symptoms such as hyperactivity, anxiety, choreiform movements, or tics during exacerbations [125]. The pathophysiology of PANDAS is hypothesized to be related to IgG anti-neuronal autoantibodies produced through the process of molecular mimicry between host and group A streptococcus (GAS), which penetrate the blood-brain barrier and potentially induce neuronal signal transduction and subsequent excess dopamine release [126].

The findings of many studies, however, are inconsistent with the hypothesis of streptococcal infection inducing autoimmune-mediated antibodies to the basal ganglia and causing tic symptoms. In a case-control study of patients with TS, Sydenham chorea, autoimmune disorders, and healthy controls, IgG class anti-neural and anti-nuclear antibody titers were no longer significant when patients were stratified by age [127]. The same study also showed no significant difference in clinical symptoms depending on autoantibody positivity. Other methodologies such as enzyme-linked immunosorbent assay (ELISA) and Western immunoblotting demonstrated no total autoantibody abnormality to the caudate, putamen, and prefrontal cortex in patients with TS and PANDAS [128].

Multiple concerns about the diagnosis and treatment of PANDAS have been raised [129,130]. It is not straightforward to distinguish PANDAS from TS clinically, as they have several similarities. The onset of PANDAS overlaps with that of TS. Both PANDAS and TS have a relapsing and remitting clinical course. Symptoms of TS are typically worsened by physical and emotional stress, anxiety, or infection. A study using clinical interviews showed that the acute onset or exacerbation of tics was frequently seen in children with tic disorders (53\%), which suggests that an explosive onset of tic symptoms is not unique to PANDAS [131]. Indeed, many children with PANDAS have pre-existing tics before the diagnosis of PANDAS, and so the abrupt, dramatic, and explosive onset of tics with the GAS infection may be the natural course of tic disorders. Patients with a diagnosis of presumed PANDAS may have a predisposition to tic disorders before the onset of PANDAS: first-degree relatives of children with PANDAS had a higher rate of OCD and TS than was reported in the general population [132].

Another concern for PANDAS is that no accurate diagnostic test exists to confirm or rule out PANDAS [133]. Diagnoses of PANDAS are often made based on incomplete criteria and most patients referred to specialty clinics with a pre-diagnosis of PANDAS do not fulfill the diagnostic criteria of PANDAS [134,135]. Making a diagnosis of a streptococcal infection is not always straightforward [136]. The sensitivity of a rapid streptococcal antigen detection test was low in children without clinical GAS symptoms such as tonsillar exudate or swelling, tender cervical lymphadenopathy, fever, and absence of a cough [137]. Even a positive throat culture may represent a GAS carrier state that does not require antibiotic treatment [138]. Anti-streptococcal antibody titers such as ASO and antideoxyribonuclease B need to be interpreted carefully. A prospective study revealed that $16 \%$ of children remained positive for the homologous serotype for more than 12 months after the infection, suggesting that single elevated antibody titers are often misleading and may only indicate antibody persistence from an infection that occurred a year earlier [139]. Single time-point 
cultures and single antibody titers are not sufficient to define the infection; sequential sampling of two different antibodies is necessary to make an accurate diagnosis of GAS infection [139]. As group C and G streptococci also produce antigenically identical ASO, the elevation of the ASO is not always linked to GAS infection $[136,139]$.

Commercial antibody panel testing, such as the Cunningham Panel, is available for the diagnosis of PANDAS. This testing measures the human serum IgG level by ELISA directed against the dopamine D1 receptor, dopamine D2L receptor, lysoganglioside-GM1, and tubulin, and measures the activity of calcium/calmodulin-dependent protein kinase II [140]. However, the reliability of the Cunningham Panel is unclear. A case-control study to assess the diagnostic accuracy of the Cunningham Panel in patients with PANDAS or pediatric acute-onset neuropsychiatric syndrome (PANS), which is clinically defined by "the unusually abrupt onset of OCD and/or severe eating restrictions and at least two concomitant cognitive, behavioral, or neurological symptoms" [141], showed low sensitivities (15-60\%), variable specificities (28-92\%), and low positive predictive values (17-40\%) and negative predictive values (44-74\%) [142]. The same study also showed elevated CaMKII activity in $48 \%(10 / 21)$ of healthy controls and $66 \%(35 / 53)$ of patients with PANDAS or PANS. Moreover, at least one autoantibody titer was positive in $86 \%$ of the healthy controls compared to $92 \%$ of the patients. The European Multicentre Tics in Children Studies (EMTICS) study, a large longitudinal observational European multicenter project, investigated the role of environmental factors including GAS exposure in tic disorders [143]. The data from the EMTICS study failed to show evidence of specific neuronal surface antibodies or of GAS association with tic exacerbations in children with TS $[144,145]$. A prospective cerebrospinal fluid (CSF) analysis study with adults with TS also failed to demonstrate specific autoantibodies in the CSF [115].

The treatment of PANDAS is also controversial. The first-line treatment for acute and chronic PANDAS is a symptomatic approach using psychological and pharmacological interventions proven to benefit specific symptoms [146]. In light of the possible autoimmune mechanism, anti-inflammatory and immunomodulatory therapies (e.g., corticosteroids, non-steroidal anti-inflammatory drugs, intravenous immunoglobulins (IVIG), therapeutic plasma exchange, rituximab) have been used for the acute phase [147]. In double-blind placebo-control studies, however, IVIG did not significantly reduce tic severity or OCD symptoms $[148,149]$. In contrast, a single placebo-controlled study using IVIG and plasmapheresis for patients with severe, infection-triggered exacerbations of OCD or tic disorders, including TS, showed that plasmapheresis showed reduction of tic severity, as measured by the Tourette Syndrome Unified Rating Scale, but IVIG did not [150]. The Tourette Association of America concluded that "experimental treatments based on the autoimmune theory, such as plasma exchange, immunoglobulin therapy, or prophylactic antibiotic treatment, should not be undertaken outside of formal clinical trials" [151].

\section{Comorbidities}

Tourette syndrome is frequently comorbid with other psychiatric symptoms, such as $\mathrm{ADHD}, \mathrm{OCD}$, autistic spectrum disorder, depression, anxiety disorder, sleep disorders, migraine, and self-injurious behavior [152-158]. About $85-88 \%$ of patients with TS have at least one psychiatric comorbidity that usually appears between the ages of 4 and 10 years $[159,160]$. The most common comorbidities are ADHD and OCD. Other disorders (e.g., mood disorder, anxiety, disruptive behavior, self-injurious behavior) have been found to occur in about $30 \%$ of patients with TS [152,160]. Some of these may be part of TS (or share common etiological influences), whereas others may be less directly related. A review of this question is beyond the scope of the present review, but for instance, in the Brainstorm Consortium GWAS of 265,218 patients and 784,643 controls, TS shared a common variant genetic risk with $\mathrm{ADHD}$, major depressive disorder, $\mathrm{OCD}$, and migraine with aura [161]. Similarly, ADHD and OCD symptom clusters were genetically related to a diagnosis of TS [162]. 
Although TS and chronic tic disorders were associated with a higher risk of premature death, irrespective of the presence of comorbidities such as ADHD, OCD, and substance abuse, in a prospective cohort study [163], adults with TS reported good psychosocial functioning, attainment of social milestones such as graduating from school, securing a job, and getting married, and high quality of life $[39,164]$. As many people still have misconceptions about tic disorders (e.g., tics are due to psychological issues or individuals with tics cannot lead normal lives), providing anticipatory guidance at the time of the diagnosis of TS can reassure patients and their families [164].

Even when tic symptoms do not impair social, behavioral, or emotional functioning, comorbidities can negatively affect patients' quality of life more than tics do $[153,165,166]$. Similarly, parents of children with tics reported that non-tic-related symptoms are more problematic than tics themselves [167]. A large clinical follow-up study of children and adolescents with TS showed an age-related decline in tics, ADHD, and OCD during adolescence, although other symptoms, such as sleep disturbance, remained [40]. Keeping in mind these comorbidities and their adverse consequences is important, and repeated assessment for them is warranted.

\subsection{Attention-Deficit Hyperactivity Disorder}

Attention-deficit hyperactivity disorder is characterized by inattentiveness, hyperactivity, and impulsivity that interferes with functioning or development. The average prevalence of ADHD in patients with TS is about 50-60\% (within the range 33-91\%), with male dominance $[159,160,168,169]$. The onset of ADHD symptoms usually precedes the onset of motor and vocal tics by an average of 2.4 years $[160,168]$. Disruptive behavior and functional impairment due to ADHD adversely influence academic, social, and family functioning [170]. Compared to pure TS, patients with TS and ADHD experience more deficits in planning, working memory, inhibitory function, and visual attention [171]. A heritability analysis involving individuals from affected sibling-pair families did not find significant genetic correlation between TS and ADHD, which suggests that high rates of ADHD in individuals with TS could be a result of increased but separate parental transmission of TS and ADHD susceptibility [172]. A case-control family study showed that ADHD and TS were not necessarily alternate manifestations of a single underlying genetic cause, but an increased risk of ADHD and TS in affected families may suggest an overlap in neurobiology and pathophysiology [173]. A GWAS also suggested modest shared etiological overlap between ADHD and TS [161].

The product labeling for stimulant medications recommends against their use in patients with tics and many clinicians still share this concern. However, substantial evidence has now accrued to dispel the idea that stimulants are contraindicated in children with tics $[174,175]$. An observational study of children and adolescents with ADHD found that new onset of tic disorder was actually less common in children treated with stimulants and tics remitted earlier in children who took stimulants [176]. A year-long, randomized, placebo-controlled trial of children with ADHD found the development of clinically significant tics to be equally common in children assigned to methylphenidate or placebo, and furthermore tics improved with treatment in two thirds of the children with a previous history of tics [177]. Most compellingly, a large, randomized, controlled trial involving children with TS and ADHD demonstrated a small but substantially significant improvement of tics with methylphenidate [178]. A meta-analysis concluded that methylphenidate did not worsen tic symptoms [179]. Additionally, a single dose of dexmethylphenidate transiently improved tic severity in a double-blind study [180]. Clinicians do observe occasional patients in whom a stimulant seems to induce or worsen tics. In the year-long study noted above, $23.6 \%$ of the children on an active drug developed moderate to severe tics for the first time- but so did $22.2 \%$ of the children on placebo! Thus, although it remains possible that methylphenidate may truly worsen tics in the occasional child, on average it is more likely to improve tics, and worsening with the drug is most likely to be coincidental. Thus, clinicians treating patients with tics and ADHD can use methylphenidate for the 
treatment of ADHD symptoms. However, given the warning in the product labeling, clinicians should explain the matter to caregivers when prescribing and monitor patients closely. Amphetamines have not been tested as carefully in tic patients, and in fact there is some evidence that children with tics tolerate methylphenidate better than amphetamine [181].

\subsection{Obsessive-Compulsive Disorder}

Obsessions are intrusive and unwanted images or thoughts that occur repetitively, and compulsions are behaviors that are performed to reduce the obsession or relieve obsession-related anxiety. The diagnosis of OCD requires OCD symptoms that are timeconsuming (at least $1 \mathrm{~h}$ per day) or cause significant clinical distress or social or occupational functional impairment [5]. Lifetime prevalence rates of OCD in patients with TS are estimated to be $30-50 \%[160,182]$, whereas the general prevalence of OCD among adults is $1-3 \%[183,184]$. The OCD symptoms in patients with TS usually begin within a few years after the onset of tics $[160,185,186]$. As TS and OCD can occur in clusters in families, a shared genetic architecture has been suggested, but a possible different underlying genetic susceptibility for TS and OCD compared with OCD alone has also been suggested [187,188].

Obsessive-compulsive disorder and TS have some common characteristics, such as a chronic waxing and waning course, premonitory phenomena preceding movement, and repetitive behavior $[185,189]$. Interestingly, obsessive-compulsive behaviors of TS differ somewhat from those of pure OCD. Contamination fears and negative thoughts (e.g., something going wrong, becoming sick, or something bad happening) are more prevalent in patients with pure OCD than in patients with TS and OCD [190]. In contrast, patients with TS tend to have compulsions such as counting, checking, ordering, arranging, touching, and hoarding as well as aggressive, sexual, religious, and symmetry obsessions [191]. Moreover, "just right" perception, where patients need to perform the same action repeatedly until they feel "just right," is characteristic of TS with OCD [192]. The "just right" sensation can be distinguished from other premonitory urges in that the "just right" perception relates to a mental phenomenon (e.g., a want), whereas the premonitory urge involves a bodily sensation (e.g., an itch).

Trichotillomania is characterized by recurrent pulling out of hair and can be seen in both TS and OCD. Due to its repetitive nature, trichotillomania is generally considered part of the OCD spectrum, but trichotillomania has some common features with TS. Trichotillomania is typically preceded by urges but not obsessions and can be treated similarly to tics (e.g., antipsychotics and habit-reversal training) [193]. Similarly, skin picking is diagnosed separately in DSM-5, but has also long been considered a complex tic [194].

\subsection{Anxiety and Depression}

Anxiety and depression each occur in about $30 \%$ of patients with TS [160]. The highrisk age period begins around 4 years for anxiety disorders and around 7 years for mood disorders [160]. Comorbid depression positively correlates with tic severity [195]. Tourette syndrome patients with depression often have a positive family history of depression [195]. About $10 \%$ of youth with tic disorders experience suicidal thoughts and attempts, which often occur in the context of anger and frustration $[196,197]$. Although there is no correlation between suicidal ideation and tic severity, the presence of anxiety and depression increases the risk of suicidality in patients with tic disorders [196]. In a large epidemiological cohort study from the Swedish National Patient Register, adults with TS had about a four-fold higher risk of both suicide attempt and death [198]. It is therefore important to assess depression and anxiety symptoms, especially in patients with a positive family history of depression.

\subsection{Other Neuropsychological Symptoms}

Eating disorders such as anorexia nervosa and bulimia nervosa are present in $2 \%$ of patients with TS, with female predominance and onset in adolescence (15-19 years old) [160]. Retching and vomiting may be symptomatic of tics if they occur alongside 
other tics and are accompanied by signs of tics such as suppressibility and premonitory urges [199]. However, medications for the treatment of TS symptoms, such as selective serotonin reuptake inhibitors and alpha-2 adrenergic agonists, can cause retching and vomiting [199]. Thus, clinicians caring for TS patients with gastrointestinal symptoms need to be aware of these possible causes.

Disruptive behaviors and rage episodes including explosive anger, temper outbursts, irritability, and aggressiveness are reported in $25-70 \%$ of TS patients [200]. The rage symptoms seem to be more closely correlated with the presence of other comorbid symptoms such as ADHD, OCD, and depression rather than tic severity [201]. Aggressive obsessions and compulsions, impulse dysregulation such as episodic rages, and risk-taking behaviors correlate with self-injurious behavior in TS [202]. Oppositional defiant disorder is reported in approximately $11-54 \%$ of TS patients and conduct disorder in approximately $6-20 \%$ [203].

Children with tics are at higher risk of being bullied and experiencing difficulties in socializing due to the social stigma [204]. Difficulties in school or the workplace often lead to discrimination, which may lower their self-esteem [204]. Poor self-perception and self-esteem are also related to the presence of comorbid psychiatric symptoms such as OCD, ADHD, and anxiety disorder [205]. The quality of life of patients with tic disorders is tied to their self-perception, so clinical treatment should focus on their self-concept and self-esteem [205]. Schizotypal personality disorder occurs in 15\% of specialty clinic patients with TS and is associated with the presence of multiple psychiatric comorbidities [206]. Although patients with TS occasionally exhibit socially unacceptable behaviors, they rarely commit criminal acts [207].

\subsection{Sleep Disorder}

Sleep disorders occur in $64 \%$ of patients with TS [154]. Even after adjusting for potential confounding factors for sleep disorders, such as obesity, asthma, allergic rhinitis, anxiety, and depression, TS has been found to independently increase the risk of difficulty with sleep initiation and sleep maintenance, parasomnia, abnormal arousal, and excessive daytime sleepiness [154,208-210]. A polysomnographic study demonstrated that both motor and vocal tics are observable during all stages of sleep [208]. The likelihood of sleep disturbance is higher when ADHD or OCD is present [211,212]. Moreover, sleep disturbances themselves can aggravate tic symptoms in the daytime [211]. Treatment of sleep problems in patients with tics may therefore reduce the severity of tics as well as improve the sleep disorders themselves.

\subsection{Headache}

A headache is a common symptom in TS. A prospective questionnaire interview study showed that about $55 \%$ of children and adolescents with TS experience headache symptoms [213]. Migraine has been reported in about $17-27 \%$ of patients with TS with a mean age of 11.9 years $[155,213,214]$. This prevalence is higher than that of general school-aged children $(2-10 \%)$ and adults $(10-13 \%)[155,214]$. Tension-type headache is also commonly seen in patients with tics. The interview study also reported that $28 \%$ of children and adolescents with TS had tension-type headaches, and the prevalence of tension-type headache is more than five times higher in tic patients than in the general pediatric population [213]. The exact mechanism of headaches in TS has not been elucidated, but a defect in serotonin metabolism has been suggested for migraine and tension-type headaches $[155,213]$. The GWAS showed significant positive correlations between migraine and TS [161].

\subsection{Learning Disability}

It is widely accepted that tic disorders do not affect intelligence and that most children with tics have normal or above normal intelligence. Although there is no evidence of memory or learning impairment in patients with TS [215], various factors such as tic 
severity, use of medication for tics, executive dysfunction, and coexisting ADHD, OCD, or other psychological illnesses can affect performance in school [216,217]. In a case-control study comparing children with TS only to children with TS and ADHD or highly suspected ADHD, learning disability was present in $23 \%$ of the children but only in those with TS with ADHD or highly suspected ADHD, not in those with TS only [218]. Patients with TS and tic disorders who seek treatment are more likely to underachieve academically across all educational levels, even after accounting for various confounders and comorbidities [219]. Detecting and addressing their difficulties at school (e.g., providing extra time to finish tasks, establishing a private space to release tics) is warranted to support their educational needs and enable them to reach their academic potential [219].

\section{Treatment and Management}

Given the frequently benign outcome and prognosis of tics, patients usually do not need to be referred to specialists. Adequate education for patients, family members, and schools is sufficient. If tics are severe and bothersome enough to affect quality of life, activities, or self-esteem, or cause significant social, emotional, and physical impairments, it is appropriate to refer the patient to specialists including pediatric neurologists, psychiatrists, psychologists, and behavioral therapists, depending on what problems most bother the patient.

Treatment and management of tic disorders begin with an assessment of tic frequency and severity and the presence of comorbid symptoms. To assess the frequency and severity of tic symptoms, the Yale Global Tic Severity Scale (YGTSS) is often used in clinics [220]. The YGTSS is a semi-structured clinical rating instrument for the assessment of tic severity in children, adolescents, and adults [194]. It is important to identify whether tics or comorbidities cause functional or emotional impairment. Unless tics are bothersome to patients, supportive care, reassurance, and education of the patient, family, and school are usually sufficient. The discussion should cover the diagnosis, the natural history of the disorder, activities or conditions that could worsen their tics, comorbidities, and indications for treatment. It is also important to debunk myths and misconceptions promulgated by stereotyped social media images. For example, many guardians and patients believe that TS is caused by stress or neglect; that tics will always progress to non-stop motor tics and socially inappropriate behaviors such as cursing; and that individuals with tics are intellectually impaired and cannot lead normal lives. In the U.S., the Tourette Association of America, a non-profit voluntary organization, and the Centers for Diseases Control and Prevention provide comprehensive materials to guardians and patients about TS and tic disorders in a variety of languages.

Pharmacological tic-suppressing treatment and behavioral therapy should be considered when tics cause physical, emotional, or social impairment (e.g., musculoskeletal injury, peer relation difficulty such as bullying, disruptive tic behaviors, low self-esteem, or difficulty in conducting physical or academic activities). The goal of treatment is to lessen the severity of the tics to improve the patient's quality of life.

\subsection{Behavioral Therapy}

The American Academy of Neurology practice guideline recommendations summary mentions a form of behavioral therapy as the first-line treatment for tics [221]. Ticsuppression-based behavioral interventions consist of exposure and response prevention and habit-reversal therapy or its descendant comprehensive behavioral interventions for tics (CBIT) [222]. These two forms of training can be effective for both motor and vocal tics. Exposure and response prevention consists of repeated, prolonged exposure to stimuli that tend to induce tics and practice to resist tic behavior [223]. Theoretically, patients habituate to the unpleasant tic-provoking sensations, thus resulting in tic reduction [224]. Habit-reversal therapy consists of awareness training and competing-response training to encourage tic suppression for long periods of time [225]. Awareness training consists of selfmonitoring tics and identifying early signs or warning signs, such as the premonitory urge. 
Competing-response training involves engagement in an active voluntary response that is incompatible with tics, such as tensing muscles antagonistic to tic-related muscles $[225,226]$. In clinical practice, patients and therapists first determine a tic hierarchy from most to least distressing and then first address the most distressing tic [225]. With practice, patients will be able to perform the competing response more effectively and efficiently [225]. A multicenter randomized controlled study of children and adults with TS comparing CBIT to psychoeducation and supportive therapy (PST) was conducted to analyze potential moderators for CBIT vs. PST or predictors of outcome [227]. Although both participants on tic medication and those not on tic medication showed response to CBIT, those on tic medication also reduced tic severity after PST. The study also showed that the presence of comorbid ADHD, OCD, or anxiety disorders, age, sex, "family functioning, tic characteristics, and treatment expectancy did not moderate response" to CBIT. A clinical study of children with tic disorders who underwent CBIT suggested that a positive response to CBIT was associated with improvement in anxiety, disruptive behavior, family strain, and social functioning at 6 months after treatment [228]. In a randomized controlled study of adolescents and adults with tics, those who received CBIT had less severe tics on the YGTSS than those who received PST at 6-8 years follow up [229].

The most widely accepted behavioral therapy for tic disorders is CBIT, which consists of habit reversal therapy, psychoeducation, functional intervention, and relaxation training [221,230]. It is safe, has no known adverse effects, and can be used by children and adults to help to reduce the severity of tics $[225,231]$. Although these therapies can eventually diminish the urges and decrease tic frequency and severity, finding a trained therapist can be difficult. Recently, Internet-based training programs have been made available to solve this issue. For example, "TicHelper" is an interactive, self-administered online CBIT program for school-age children. It is an 8-week program designed to teach tic management skills where children and guardians can learn about tics, such as how to reduce tic triggers and employ tic-blocking techniques [232]. "TicTrainer" is a free but untested Internet-based tic suppression training program consisting of a reward-enhanced exposure and response prevention strategy. Users attempt to suppress their tics to gain rewards, as if they were playing a video game. For example, they earn points for tic suppression and the longer they suppress their tics, the more points they earn [233]. Internet-based behavioral therapy gives patients and guardians more access to evidence-based therapies and may be effective in the long run [234]. Furthermore, group-based behavioral therapies have been developed to provide the behavioral therapies for more patients [235]. It likely will prove more cost-effective than individual therapies, and provides an opportunity for patients to meet other patients and to share their experiences and support.

\subsection{Other Non-Pharmacological Treatment}

Various complementary and alternative medicines have been used for the treatment of tics, including prayer, vitamins, massage, dietary or nutritional supplements (e.g., the $B$ vitamins, vitamins C, D, and E, calcium, magnesium, Coenzyme Q10, fish oil), chiropractic manipulations, meditation, diet, yoga, acupuncture, hypnosis, homeopathy, and biofeedback $[236,237]$. Acupuncture may be effective for the treatment of tics for a short period, but the evidence is limited due to biases [238]. Without randomized controlled studies to establish dosing, safety, and efficacy, we do not know which of these have specific benefit beyond any placebo effect [237]. Since patients often pursue complementary and alternative medicines without informing their physicians, the treating physician needs to ask about these therapies [236].

\subsection{Pharmacological Treatment}

Pharmacological treatment should be considered when behavioral interventions fail or are not available (e.g., lack of access to behavioral therapies, including expense, or patient factors such as age, cognition, or willingness to participate) or when patients exhibit severe, violent tics that need immediate treatment. Before starting patients on a course of 
medication, clinicians must explain the purpose and set a realistic goal-that is, to reduce the severity and frequency of tics to the extent that they no longer bother the patient or cause significant problems.

Various therapeutic algorithms have helped clinicians choose medicines for the treatment of tics. One approach is to focus solely on efficacy, as the recent review of evidence from the American Academy of Neurology does [239]. However, in clinical practice, other factors, including side effect risk, cost, and convenience also play a role [221]. For instance, many families are more concerned about risk than about immediate benefit. Thus, we and several other authors prefer an approach that includes two tiers of medicines based on tic severity [240-242]. The first-tier medicines are for mild tics, when tolerability may be more important than proven efficacy, and the second-tier medicines are for severe tics or tics that are resistant to the first-tier medicines. As a rule, the medicines should be started on a low dose with gradual titration until they become effective. Once the symptoms subside to such a degree that the tics are no longer bothersome, physicians should discuss weaning off the medicines with patients and caregivers. The trial of weaning off the medicines should be undertaken only when the patient is mentally and physically healthy and does not anticipate any stressful situations or events.

\subsubsection{First-Tier Medicines}

Medicines in this category are non-dopaminergic agents that are mildly to moderately effective in tic suppression and do not have severe adverse effects. The typical medicines in this category are alpha-2-adrenergic agonists such as clonidine and guanfacine [243]. As the alpha-2-adrenergic agonists are useful for the treatment of ADHD in children and adolescents [244,245], both tics and ADHD symptoms may improve. Clonidine is frequently used for the treatment of tics. The Tourette's Syndrome Study Group conducted a large randomized controlled trial involving children with TS and ADHD to investigate the efficacy of clonidine and methylphenidate for tics and ADHD [178]. The children who took both clonidine and methylphenidate showed the most improvement, followed by those who took only clonidine. In addition to an oral preparation of clonidine, an adhesive transdermal patch is available. A randomized controlled study of children with tic disorders showed its efficacy and safety in tic treatment [246]. The recommended starting dose of clonidine is $0.025-0.05 \mathrm{mg} /$ day, and it should be slowly titrated up to a therapeutic range of $0.1-0.3 \mathrm{mg} /$ day $[247,248]$. The maximum total daily dose is $0.4 \mathrm{mg} /$ day, divided up to 4 times a day with the highest single dose being $0.2 \mathrm{mg}$ [249]. The side effects of clonidine include sedation, drowsiness, lightheadedness, tiredness, irritability, dry mouth, bradycardia, and hypotension. Although electrocardiogram monitoring is not necessary [250], close monitoring of blood pressure and heart rate is essential. Due to the side effect of sleepiness, clonidine may be useful for patients with tics who have difficulty with sleep initiation.

Guanfacine is another alpha-2 adrenergic agonist that has been used for the treatment of high blood pressure and ADHD. Its therapeutic effect for tics has been reported in openlabel studies of children with TS and ADHD [251,252] and a placebo-controlled clinical trial of children with TS and ADHD [253]. The adverse effects are similar to those of clonidine, such as fatigue, drowsiness, dry mouth, headache, and irritability [254]. Guanfacine acts on alpha-2 receptors of neural cells more selectively than clonidine does, and it has a longer half-life and less severe adverse effects such as sedation and dizziness [255]. Thus, guanfacine is often more favored than clonidine. However, a randomized double-blind study of the extended-release formulation of guanfacine in children with moderate-to-severe chronic tic disorder did not show a clinically meaningful effect for tic suppression [254]. The recommended starting dose of guanfacine is $0.5-1.0 \mathrm{mg} /$ day, and it should be titrated slowly up to a therapeutic range of $1.0-4.0 \mathrm{mg} /$ day $[247,248]$.

Based on a hypothesis that inhibitory GABA signaling dysfunction in the basal ganglia underlies the pathology of TS [256], GABAergic medications such as antiepileptic drugs and baclofen have been used for the treatment of tics. Evidence of the efficacy of these 
medicines is not as robust as that of alpha-2 adrenergic agonists, but these medicines can be used as a monotherapy or as add-on therapy in the treatment for tics.

Topiramate is a broad-spectrum antiepileptic drug that enhances GABAergic activity and inhibits kainate/AMPA glutamate receptors [257]. An open-labeled study and a randomized double-blind study of children and adolescents with TS showed moderate efficacy and a statistically significant reduction in the YGTSS $[258,259]$. Adverse effects included headache, diarrhea, abdominal pain, drowsiness, cognitive slowing, and kidney stones [258]. The starting dose is $25 \mathrm{mg} /$ day, and it should be titrated up gradually to 50-200 mg/day depending on efficacy and tolerability [258].

Levetiracetam is an antiepileptic medicine that enhances GABA inhibition of neuronal circuits [260]. Open-label studies of children and adolescents with TS showed statistically significant improvement of tic symptoms [261,262]. Their behavioral and school performance also improved with levetiracetam [261]. On the other hand, randomized doubleblind studies of children and adults with TS showed no reduction in tic severity or improvement in behavioral scores $[263,264]$. Adverse reactions include irritability and somnolence. The initial dose of levetiracetam is $20 \mathrm{mg} / \mathrm{kg} /$ day or $250 \mathrm{mg} /$ day [261,262]. The dose is increased gradually up to $30-40 \mathrm{mg} / \mathrm{kg} /$ day, with a maximum dose of $60 \mathrm{mg} / \mathrm{kg} /$ day or $2000 \mathrm{mg} /$ day [261,262].

Clonazepam is a benzodiazepine that has been used for the treatment of seizures and panic attacks. It acts on benzodiazepine receptors, increasing the effect of GABAergic transmission [265]. A case report of a 13-year-old boy with TS showed that his tics improved with clonazepam [266]. A single-blind study of patients with TS who had high ratios of red blood cell to plasma choline levels showed more response with clonazepam than haloperidol [267].

Baclofen is a GABA B receptor agonist and has been used for the treatment of spasticity. A large cohort open-label study of children with TS revealed a significant reduction in the severity of tics [268]. A double-blind, placebo-controlled crossover trial of children with TS demonstrated a reduction in tic severity, as measured by the YGTSS, although the reduction was not statistically significant [269]. Common side-effects are sedation and drowsiness [268]. The starting dose is $10 \mathrm{mg} /$ day, and it can be increased gradually by $10 \mathrm{mg} /$ day weekly, depending on the patient's symptoms, up to $80 \mathrm{mg} /$ day (mean $30 \mathrm{mg}$ /day) [268].

\subsubsection{Second-Tier Medicines}

Medicines in this category are dopamine receptor blocking agents (DRBA) (e.g., typical and atypical neuroleptics). Abnormal dopaminergic activity is considered to be involved in the mechanism of TS [270]. Specifically, D2 receptor blocking agents reduce tic severity by about $70 \%$ [248]. They are more effective in tic suppression than the first-tier medicines but cause more adverse effects such as sedation, metabolic syndrome (e.g., obesity, insulin resistance, hypertension, and dyslipidemia), akathisia, dystonia, or rigiditybradykinesia [271,272].

Cardiovascular adverse effects such as torsades de pointes, QTc prolongation, myocarditis, and cardiomyopathy can be life-threatening [273,274]. Antipsychotic-induced tardive dyskinesia (TD) is also common in schizophrenia affecting approximately $21 \%$ of patients with schizophrenia receiving atypical neuroleptics and $30 \%$ receiving typical neuroleptics [275]. However, TD is apparently quite rare in TS. The classic symptoms of TD are involuntary, repetitive hyperkinetic movement around the mouth (e.g., chewing, protrusion of the tongue, jaw movements, lip-smacking, or puckering) [276]. The dyskinesia usually emerges insidiously and can occur after short-term or long-term use of neuroleptics [277]. TD can be distinguished from tics by the time course and by several other features, including that TD is usually rhythmic at $0.5-2 \mathrm{~Hz}$, does not include premonitory phenomena, and is perceived by the patient as truly involuntary. The DSM-5 describes TD as medication-induced dyskinesia that occurs in the following conditions: (1) during exposure to a DRBA for at least three months, or one month in patients aged 
60 years or older; (2) within four weeks of withdrawal from an oral medicine or within eight weeks from a depot medication. The symptoms should persist for at least one month after discontinuation of an offending agent [5]. Some experts argue that TD can occur within one year after exposure to DRBAs [277]. By definition, TD symptoms persist for at least one month after the discontinuation of medicine [278]. A rapid reduction or sudden discontinuation of the medicine may lead to transient worsening of dyskinesia, known as withdrawal dyskinesia $[275,279]$. Slow and gradual tapering of the offending medication over a period of weeks or months is recommended for patients who develop TD and do not have a psychiatric illness [280], though limited evidence supports slow tapering vs. abrupt discontinuation. Although many patients with TD showed some improvement within the first year of discontinuation of the neuroleptic, the chance of complete remission has been reported to be low in both psychiatric and non-psychiatric patients [281,282].

The medications approved by the U.S. Food and Drug Administration (FDA) for the treatment of tics are haloperidol, pimozide, and aripiprazole. Haloperidol is a D2 receptor antagonist and was reported to be effective for tic treatment in the early 1960s [283,284]. A case series [285] and a double-blind placebo-controlled study [286] demonstrated a similar therapeutic effect. A double-blind crossover study of haloperidol, pimozide, and a placebo revealed that haloperidol was slightly more effective than pimozide [287]. However, in a placebo-controlled double crossover study of children and adolescents with TS, haloperidol failed to provide significant benefit in tic reduction and was inferior to pimozide in tic suppression [288]. Furthermore, haloperidol causes more lethargy and extrapyramidal side-effects than pimozide $[286,288,289]$. Haloperidol is therefore not regarded as a preferred treatment for tic suppression but instead is recommended for patients who have not responded to other tic-suppressing medicines [290]. The starting dose is usually $0.5 \mathrm{mg} /$ day, and it should be titrated gradually by $0.25-0.5 \mathrm{mg}$ every $5-7$ days. The typical dose ranges from $2 \mathrm{mg}$ to $10 \mathrm{mg}$ daily [290].

Pimozide is a potent DRBA and has been reported to be effective in tic suppression in clinical studies [291-294]. A prospective and double-blind clinical cohort study of children with TS demonstrated that pimozide was effective in the short and long term [295]. Arrhythmias such as QT prolongation and decreased blood pressure have been associated with patients receiving pimozide [287,296-298]. The starting dose is usually $0.05 \mathrm{mg} / \mathrm{kg}$ daily, and it should be gradually increased to $0.2 \mathrm{mg} / \mathrm{kg}$, not exceeding $10 \mathrm{mg} /$ day [299]. Because coadministration of potent cytochrome P450 (CYP) 2D6 inhibitor (e.g., sertraline) can increase pimozide concentration [300] and the arrhythmogenic side-effects of pimozide are concentration-dependent [301], the FDA recommends CYP2D6 genotyping [299]. In poor CYP2D6 metabolizers, the maximum dose should not exceed $0.05 \mathrm{mg} / \mathrm{kg} /$ day, and titration should be no faster than every 14 days [299].

Aripiprazole is an atypical neuroleptic that is approved by the FDA for the treatment of tics. It is a dopamine-serotonin partial agonist, acting as a partial D2, D3, and D4 receptor agonist, as well as a partial 5-HT1A, 5-HT2A, and 5-HT2C agonist [302]. A large multicenter, double-blind, randomized placebo-controlled study of children and adolescents with TS demonstrated that aripiprazole was superior to placebo in the reduction of tics with good tolerability [303]. Compared to pimozide, aripiprazole has a safer cardiovascular profile [297] and is generally quite well tolerated. The starting dose of aripiprazole is usually $1.25-2.5 \mathrm{mg} /$ day, with gradual titration from $2.5 \mathrm{mg} /$ day to $20 \mathrm{mg} /$ day divided into two doses according to tic severity and tolerability [290,304].

Risperidone is frequently used for the treatment of tics, although it is not FDAapproved for this indication. It acts as a D2 and 5-HT2 receptor antagonist [305]. Risperidone may effectively reduce aggressive behavior as well as tic severity in patients with TS [306]. An open-label trial [305] and a randomized, double-blind, placebo-controlled trial [307] of patients with TS showed that risperidone reduces tic severity. A randomized, double-blind, parallel-group clinical trial of children with TS investigating the efficacy and tolerability of risperidone and clonidine demonstrated that risperidone was as effective as clonidine for the treatment of tic symptoms [308]. The adverse effects of risperidone 
include sedation, extrapyramidal symptoms (e.g., acute dystonic reactions, parkinsonism, and akathisia), orthostatic hypotension, hyperprolactinemia, gynecomastia, and weight gain. The starting dose is $0.25 \mathrm{mg}$ daily, and it should be increased slowly every 5-7 days up to $0.25-4.0 \mathrm{mg}$ daily [290].

Olanzapine is an atypical neuroleptic with a multiple-receptor-blocking profile including D1-D4, 5-HT, muscarinic, and histaminergic antagonists [309], and it has also been investigated for the treatment of tics. A clinical trial of children with TS showed that olanzapine was effective for tic suppression and aggression, but significant weight gain was noted [310]. Due to its important side-effects such as weight gain and sedation or drowsiness, olanzapine must be used cautiously in children [311]. Olanzapine is started at $2.5-5.0 \mathrm{mg} /$ day and titrated every 5-7 days to a maximum of $30 \mathrm{mg} /$ day [290].

Ziprasidone is an atypical neuroleptic and acts mainly as a 5-HT and D2 receptor antagonist and blocks other neurotransmitters [312]. A randomized, double-blind, placebocontrolled trial of children and adolescents with TS showed that ziprasidone reduced tics significantly and was tolerated well [313]. Unlike other atypical neuroleptics, ziprasidone does not appear to cause weight gain and extrapyramidal symptoms but is associated with a dose-dependent QTc interval prolongation [314]. Thus, patients with cardiac arrhythmia risk should avoid ziprasidone therapy. Ziprasidone is started at $5-10 \mathrm{mg} /$ day and titrated slowly every week to a maximum of $40 \mathrm{mg} /$ day [290].

Ecopipam is a selective D1 receptor agonist and has drawn attention as a treatment for tics. A randomized, placebo-controlled crossover study of children and adolescents with TS showed that ecopipam reduced tics significantly and was well tolerated [315]. Adverse events included gastrointestinal symptoms, decreased appetite, fatigue somnolence, headache, insomnia, rash, and nasopharyngitis, but no serious side effects were reported.

Compared to neuroleptics that block dopamine receptors, dopamine-depleting agents that deplete presynaptic dopamine by blocking the vesicular monoamine transporter type 2 (VMAT2) are safer with little or no risk of TD and have been used in the treatment of movement disorders such as chorea, TD, and tics [316]. Tetrabenazine is an FDA-approved medicine for the treatment of chorea associated with Huntington's disease. Open-label clinical studies of patients with TS showed that tetrabenazine improved their tics and TS-related symptoms $[317,318]$. Side effects of tetrabenazine include drowsiness, sleepiness, akathisia, parkinsonism, and depression, which can be controlled by adjusting the dose [319]. Tetrabenazine is usually reserved for patients with severe tics who did not respond to or cannot tolerate other tic medicines. Importantly, tetrabenazine carries a black box warning regarding possible deterioration of an already present depression and should be used cautiously [319]. Although open-label studies suggested benefit of VMAT2 inhibitors for tics [320-322], controlled trials of two tetrabenazine derivatives in TS unfortunately failed to show efficacy. An open-label study of children and adolescents with TS failed to show benefit of valbenazine, which is a purified parent drug of the $(+)-\alpha$-isomer of tetrabenazine [323]. The other trial failed to show significant benefit of deutetrabenazine, a deuterated from of tetrabenazine (ARTISTS1; NCT03452943) (https: / / clinicaltrials.gov / ct2 / show / results / NCT03452943 (accessed on 01 June 2021)).

\subsubsection{Other Treatment}

Aside from oral pharmacological treatment, botulinum toxin injections have been used in the treatment of spasticity and movement disorders [324]. Botulinum toxin's mechanism of action is to inhibit the release of neurotransmitters (e.g., acetylcholine) from the presynaptic nerve terminal by cleaving soluble N-ethylmaleimide-sensitive factor attachment protein receptor proteins, which are essential for presynaptic vesicle fusion [325]. An injection of botulinum toxin into muscles that cause tic movements improves tic symptoms but also reduces the premonitory urge [326,327]. Similarly, injection into the vocal cords also improves vocal tics and the premonitory urge [328]. Treatment with botulinum toxin should be considered in patients with severe self-injurious motor tics (e.g., repetitive cervical extension) to prevent the progression of disabling myelopathy [329]. 
Deep brain stimulation (DBS) is a neurosurgical procedure to implant a device called a neurostimulator to deliver electrical stimulation to a targeted brain region and may be a promising treatment for patients with tics [330]. Reported targets for DBS include the thalamus, globus pallidus internus, globus pallidus externus, anterior limb of the internal capsule, and nucleus accumbens [331]. The International Deep Brain Stimulation Database and Registry demonstrated that the overall adverse event rate was $35.4 \%$ including intracranial hemorrhage (1.3\%), infection (3.2\%), and lead explantation $(0.6 \%)$, and stimulation-induced side effects such as dysarthria (6.3\%) and paresthesia (8.2\%) [330]. Some work has found improvement in over $50 \%$ of patients [332-334], whereas other reports suggest that the likelihood of benefit may vary as much as $9-82 \%$ [335]. Further studies are needed to identify the optimum target, benefits and risks, indications, timing for the procedure, and stimulation parameters [336].

Although hospital admission due to tics is very rare, about $5 \%$ of patients with TS who were referred to a movement disorder clinic exhibited life-threatening tics, known as "malignant TS" [332]. Life-threatening and dangerous self-injurious tic behaviors such as hyperextension of the neck are indications for hospital admission [332]. If patients have suicidal ideation, psychiatric hospital admission will often be warranted. Treatment for malignant TS is challenging. The first-tier and second-tier tic medicines are used, but may not be effective. Behavioral therapy or CBIT may be used with some benefit. For cases refractory to behavior therapy and medication, DBS of the globus pallidus interna or centromedial thalamus may be an option. Abrupt withdrawal of neuroleptics or clonazepam may lead to severe, disabling, and continuous tics, referred to as "tic status." Tic status may interfere with activities and sleep, can be refractory to tic-suppressing medicines, and may require sedation with propofol and midazolam [337].

\section{Differential Diagnosis}

Various movements may resemble tics, from the common (e.g., habits, stereotypies, and mannerisms) to the abnormal (e.g., compulsion, chorea, dystonia, and myoclonus). To distinguish such movements from tics, one can confirm the presence of the premonitory urge, suppressibility, and suggestibility, as well as the phenomenology and timing of the movements.

Habits (and body-focused repetitive behaviors) are movements elicited by environmental stimuli or contexts and not performed to obtain future outcomes (e.g., nail biting, picking, thumb sucking, and hair twirling) [338]. Stereotypies are described as repetitive, patterned, non-purposeful movements (e.g., body rocking, tapping, hand flapping, arm waving) that stop with distraction or calling the child's name, are frequently seen in early childhood, and may persist until adolescence with gradual reduction in frequency and duration [339]. They can occur in otherwise healthy children and in children with ADHD, OCD, anxiety, and autistic spectrum disorder [340]. Tics and stereotypies may coexist but may be differentiated by certain features. Stereotypies usually begin before the age of 3 years, which is earlier than the onset of tics, and they tend to improve during childhood [341]. Compared to tics, stereotypies are longer in duration, rhythmic, and less variable in type, location, and severity over time [341]. The premonitory urge is not seen in patients with stereotypies. Stereotypies often provide a comforting, enjoyable, and pleasing experience for children, in contrast to the discomfort and distress of tics [340]. Reassurance and psychoeducation are usually appropriate for stereotypies, but in some patients they can reduce quality of life, and in these patients, behavioral therapies such as habit-reversal training or response interruption and redirection can reduce the severity and frequency of stereotypies, while pharmacotherapy is usually not effective [342]. The use of an instructional DVD as a home-based, parent-administered behavioral therapy has been shown to reduce stereotypies by $15-24 \%$ [343].

Mannerisms are repetitive and unusual habits or gestures unique to the individual $[344,345]$. Mannerisms can be seen not only in healthy individuals but also in patients 
with schizophrenia with delusions [346]. Unlike tics, mannerisms may be goal-directed (e.g., performing a ritualistic action for luck) $[345,346]$. Mannerisms do not require treatment.

Compulsions are repetitive behaviors (e.g., hand washing) or mental acts (e.g., praying, counting) that are performed in response to an obsession or to prevent distress [5]. Some complex motor tics such as touching, tapping, and knocking resemble compulsions. Clinically, compulsions are associated with specific, sometimes ritualistic rules, or are performed in response to an obsession to reduce anxiety, distress, or discomfort [347]. Unlike patients with tics, those with compulsions do not experience premonitory sensations. Compulsions and complex tics may both occur in patients but distinguishing between them can be important to guiding treatment of the most bothersome symptoms. Compulsions improve with treatments for OCD, such as behavior therapy or serotonin reuptake inhibitors.

Chorea is characterized by brief, abrupt, irregular, unpredictable, purposeless, nonstereotyped movements flowing randomly from one part of the body to another [348]. Damage or dysfunction of the interconnection between the motor cortical areas and the basal ganglia, including the caudate nucleus, putamen, globus pallidus interna and externa, and associated structures such as the subthalamic nucleus and substantia nigra, leads to deficient inhibition to the thalamus and excessive thalamocortical motor facilitation, resulting in chorea movements [349]. The etiologies of acute chorea include autoimmune disease, infection, vascular disease, mitochondrial disease, toxins, and functional disease and those of chronic chorea include genetic, metabolic, and vascular diseases [350]. Differentiating between chorea and tics is aided by a detailed history of the disease onset, progression, and associated symptoms. Chorea may be voluntarily suppressible [37], but unlike tics, patients with chorea do not have premonitory urges. Compared to chorea, tic movements are usually more patterned and are repeated in a predictable and stereotypical manner.

Dystonia is a movement disorder characterized by involuntary sustained muscle contractions that produce abnormal postures or repetitive movements [351]. Electromyography (EMG) has shown that tonic agonist and antagonist muscle contractions occur during dystonia [352]. The etiology of dystonia is not fully understood, but structural abnormalities in the basal ganglia, cerebellum, cortex, brainstem, and thalamus, as well as neurotransmitter diseases that can affect dopaminergic dysfunction, have been suggested [353]. The most distinctive features of dystonia are sustained twisting movements, a sensory phenomenon called sensory trick (i.e., an internally generated, specific voluntary movement aimed at ameliorating the dystonia), task specificity, and directionality (e.g., alternates between quick jerking movements in one direction and slower movements in the opposite direction) [351,354]. Unlike tics, dystonia is not preceded by premonitory urges.

Myoclonus is a movement disorder characterized by brief, sudden, involuntary muscle jerks. It arises from all levels of the nervous system, including the cortical and subcortical areas, brainstem, spinal cord, and peripheral areas, and causes muscle contractions (positive myoclonus) or brief inhibition during sustained posture (negative myoclonus) [355]. Tics and myoclonus may be visibly indistinguishable, but some clinical features are useful to distinguish them. Myoclonus is very brief (traditionally $<200 \mathrm{~ms}$ on EMG), is nonsuppressible, may be unpredictable in terms of location and timing, and is not associated with a premonitory urge [356].

Author Contributions: Conceptualization, K.U.; funding acquisition, K.J.B.; writing—original draft preparation, K.U.; writing—review and editing, K.U. and K.J.B. Both authors have read and agreed to the published version of the manuscript.

Funding: This research was funded by the National Institutes of Health, grant number R01MH104030.

Acknowledgments: An earlier draft of this article was archived on the Open Science Framework (https:/ /osf.io/ehz7u) and a much shorter version will be published in "Symptom-Based Approach to Pediatric Neurology" in 2021, editors Deepak K. Kamat and Lalitha Sivaswamy.

Conflicts of Interest: K.U. declares no conflict of interest. K.J.B. reports research support from Emalex Biosciences. 


\section{References}

1. Mink, J.W. The Basal Ganglia and involuntary movements: Impaired inhibition of competing motor patterns. Arch. Neurol. 2003, 60, 1365-1368. [CrossRef]

2. Fahn, S.; Jankovic, J.; Hallett, M. Principles and Practice of Movement Disorders E-Book; Elsevier Health Sciences: Amsterdam, The Netherlands, 2011; pp. 350-379.

3. Lavoie, M.E.; O'Connor, K. Toward a Multifactorial Conception of the Gilles de la Tourette Syndrome and Persistent Chronic Tic Disorder. Brain Sci. 2017, 7, 61. [CrossRef]

4. Shapiro, A.K.; Shapiro, E. Treatment of Gilles de la Tourette's Syndrome with haloperidol. Br. J. Psychiatry 1968, 114, 345-350. [CrossRef]

5. American Psychiatric Association. Diagnostic and Statistical Manual of Mental Disorders (DSM-5®); American Psychiatric Publishing: Washington, DC, USA, 2013.

6. Singer, H.; Mink, J.; Gilbert, D.; Jankovic, J. Movement Disorders in Childhood, 2nd ed.; Elsevier: London, UK, 2016 ; pp. 40-55.

7. Ganos, C.; Bongert, J.; Asmuss, L.; Martino, D.; Haggard, P.; Münchau, A. The somatotopy of tic inhibition: Where and how much? Mov. Disord. 2015, 30, 1184-1189. [CrossRef] [PubMed]

8. Pappert, E.J.; Goetz, C.G.; Louis, E.D.; Blasucci, L.; Leurgans, S. Objective assessments of longitudinal outcome in Gilles de la Tourette's syndrome. Neurology 2003, 61, 936-940. [CrossRef] [PubMed]

9. Jankovic, J. Tourette's syndrome. N. Engl. J. Med. 2001, 345, 1184-1192. [CrossRef] [PubMed]

10. Kaczyńska, J.; Janik, P. Tonic Tics in Gilles de la Tourette Syndrome. Neuropediatrics 2021. [CrossRef]

11. Jankovic, J. Tourette syndrome. Phenomenology and classification of tics. Neurol. Clin. 1997, 15, 267-275. [CrossRef]

12. Jankovic, J.; Kurlan, R. Tourette syndrome: Evolving concepts. Mov. Disord. 2011, 26, 1149-1156. [CrossRef]

13. Goldenberg, J.N.; Brown, S.B.; Weiner, W.J. Coprolalia in younger patients with Gilles de la Tourette syndrome. Mov. Disord. 1994, 9, 622-665. [CrossRef]

14. Kurlan, R.; Behr, J.; Medved, L.; Shoulson, I.; Pauls, D.; Kidd, J.R.; Kidd, K.K. Familial Tourette's syndrome: Report of a large pedigree and potential for linkage analysis. Neurology 1986, 36, 772-776. [CrossRef]

15. Robertson, M.M. Tourette syndrome, associated conditions and the complexities of treatment. Brain 2000, 123, 425-462. [CrossRef]

16. Müller-Vahl, K.R.; Sambrani, T.; Jakubovski, E. Tic disorders revisited: Introduction of the term "tic spectrum disorders". Eur. Child Adolesc. Psychiatry 2019, 28, 1129-1135. [CrossRef] [PubMed]

17. Roessner, V.; Hoekstra, P.J.; Rothenberger, A. Tourette's disorder and other tic disorders in DSM-5: A comment. Eur. Child Adolesc. Psychiatry 2011, 20, 71-74. [CrossRef] [PubMed]

18. Black, K.J.; Black, E.R.; Greene, D.J.; Schlaggar, B.L. Provisional Tic Disorder: What to tell parents when their child first starts ticcing. F1000Research 2016, 5, 696. [CrossRef] [PubMed]

19. Eapen, V.; Cavanna, A.E.; Robertson, M.M. Comorbidities, Social Impact, and Quality of Life in Tourette Syndrome. Front. Psychiatry 2016, 7, 97. [CrossRef]

20. Dooley, J.M.; Gordon, K.E.; Wood, E.P.; Camfield, C.S.; Camfield, P.R. The utility of the physical examination and investigations in the pediatric neurology consultation. Pediatr. Neurol. 2003, 28, 96-99. [CrossRef]

21. Goetz, C.G.; Leurgans, S.; Chmura, T.A. Home alone: Methods to maximize tic expression for objective videotape assessments in Gilles de la Tourette syndrome. Mov. Disord. 2001, 16, 693-697. [CrossRef]

22. Bloch, M.H.; Leckman, J.F. Clinical course of Tourette syndrome. J. Psychosom. Res. 2009, 67, 497-501. [CrossRef]

23. Khalifa, N.; von Knorring, A.L. Tourette syndrome and other tic disorders in a total population of children: Clinical assessment and background. Acta Paediatr. 2005, 94, 1608-1614. [CrossRef]

24. Kim, S.; Greene, D.J.; Bihun, E.C.; Koller, J.M.; Hampton, J.M.; Acevedo, H.; Reiersen, A.M.; Schlaggar, B.L.; Black, K.J. Provisional Tic Disorder is not so transient. Sci. Rep. 2019, 9, 3951. [CrossRef]

25. Leckman, J.F.; Zhang, H.; Vitale, A.; Lahnin, F.; Lynch, K.; Bondi, C.; Kim, Y.S.; Peterson, B.S. Course of tic severity in Tourette syndrome: The first two decades. Pediatrics 1998, 102, 14-19. [CrossRef] [PubMed]

26. Black, K.J.; Kim, S.; Yang, N.Y.; Greene, D.J. Course of tic disorders over the lifespan. Curr. Dev. Disord. Rep. 2021, in press. [CrossRef]

27. Burd, L.; Kerbeshian, P.J.; Barth, A.; Klug, M.G.; Avery, P.K.; Benz, B. Long-term follow-up of an epidemiologically defined cohort of patients with Tourette syndrome. J. Child Neurol. 2001, 16, 431-437. [CrossRef] [PubMed]

28. Bloch, M.H.; Peterson, B.S.; Scahill, L.; Otka, J.; Katsovich, L.; Zhang, H.; Leckman, J.F. Adulthood outcome of tic and obsessivecompulsive symptom severity in children with Tourette syndrome. Arch. Pediatr. Adolesc. Med. 2006, 160, 65-69. [CrossRef]

29. Horesh, N.; Zimmerman, S.; Steinberg, T.; Yagan, H.; Apter, A. Is onset of Tourette syndrome influenced by life events? J. Neural Transm. 2008, 115, 787-793. [CrossRef]

30. Bliss, J.; Cohen, D.J.; Freedman, D.X. Sensory experiences of Gilles de la Tourette syndrome. Arch. Gen. Psychiatry 1980, 37, 1343-1347. [CrossRef] [PubMed]

31. Leckman, J.F. Tourette's syndrome. Lancet 2002, 360, 1577-1586. [CrossRef]

32. Woods, D.W.; Piacentini, J.; Himle, M.B.; Chang, S. Premonitory Urge for Tics Scale (PUTS): Initial psychometric results and examination of the premonitory urge phenomenon in youths with Tic disorders. J. Dev. Behav. Pediatr. 2005, 26, $397-403$. [CrossRef] [PubMed] 
33. Kwak, C.; Dat Vuong, K.; Jankovic, J. Premonitory sensory phenomenon in Tourette's syndrome. Mov. Disord. 2003, 18, 1530-1533. [CrossRef]

34. Leckman, J.F.; Walker, D.E.; Cohen, D.J. Premonitory urges in Tourette's syndrome. Am. J. Psychiatry 1993, 150, 98-102. [CrossRef] [PubMed]

35. Reese, H.E.; Scahill, L.; Peterson, A.L.; Crowe, K.; Woods, D.W.; Piacentini, J.; Walkup, J.T.; Wilhelm, S. The premonitory urge to tic: Measurement, characteristics, and correlates in older adolescents and adults. Behav. Ther. 2014, 45, 177-186. [CrossRef] [PubMed]

36. Banaschewski, T.; Woerner, W.; Rothenberger, A. Premonitory sensory phenomena and suppressibility of tics in Tourette syndrome: Developmental aspects in children and adolescents. Dev. Med. Child. Neurol. 2003, 45, 700-703. [CrossRef]

37. Koller, W.C.; Biary, N.M. Volitional control of involuntary movements. Mov. Disord. 1989, 4, 153-156. [CrossRef]

38. Ueda, K.; Kim, S.; Greene, D.J.; Black, K.J. Correlates and clinical implications of tic suppressibility. Curr. Dev. Disord. Rep. 2021, in press. [CrossRef]

39. Goetz, C.G.; Tanner, C.M.; Stebbins, G.T.; Leipzig, G.; Carr, W.C. Adult tics in Gilles de la Tourette's syndrome: Description and risk factors. Neurology 1992, 42, 784-788. [CrossRef]

40. Groth, C.; Mol Debes, N.; Rask, C.U.; Lange, T.; Skov, L. Course of Tourette Syndrome and Comorbidities in a Large Prospective Clinical Study. J. Am. Acad. Child Adolesc. Psychiatry 2017, 56, 304-312. [CrossRef]

41. Jankovic, J.; Gelineau-Kattner, R.; Davidson, A. Tourette's syndrome in adults. Mov. Disord. 2010, 25, 2171-2175. [CrossRef]

42. Cubo, E. Review of prevalence studies of tic disorders: Methodological caveats. Tremor Other Hyperkinet. Mov. 2012, 2. [CrossRef]

43. Kurlan, R.; Behr, J.; Medved, L.; Shoulson, I.; Pauls, D.; Kidd, K.K. Severity of Tourette's syndrome in one large kindred. Implication for determination of disease prevalence rate. Arch. Neurol. 1987, 44, 268-269. [CrossRef]

44. Knight, T.; Steeves, T.; Day, L.; Lowerison, M.; Jette, N.; Pringsheim, T. Prevalence of tic disorders: A systematic review and meta-analysis. Pediatr. Neurol. 2012, 47,77-90. [CrossRef]

45. Robertson, M.M. The prevalence and epidemiology of Gilles de la Tourette syndrome. Part 1: The epidemiological and prevalence studies. J. Psychosom. Res. 2008, 65, 461-472. [CrossRef] [PubMed]

46. Robertson, M.M. The prevalence and epidemiology of Gilles de la Tourette syndrome. Part 2: Tentative explanations for differing prevalence figures in GTS, including the possible effects of psychopathology, aetiology, cultural differences, and differing phenotypes. J. Psychosom. Res. 2008, 65, 473-486. [CrossRef] [PubMed]

47. Snider, L.A.; Seligman, L.D.; Ketchen, B.R.; Levitt, S.J.; Bates, L.R.; Garvey, M.A.; Swedo, S.E. Tics and problem behaviors in schoolchildren: Prevalence, characterization, and associations. Pediatrics 2002, 110, 331-336. [CrossRef] [PubMed]

48. Stefanoff, P.; Wolanczyk, T.; Gawrys, A.; Swirszcz, K.; Stefanoff, E.; Kaminska, A.; Lojewska-Bajbus, M.; Mazurek, B.; MajewskaStefaniak, A.; Mikulska, J.; et al. Prevalence of tic disorders among schoolchildren in Warsaw, Poland. Eur. Child Adolesc. Psychiatry 2008, 17, 171-178. [CrossRef]

49. Kurlan, R.; McDermott, M.P.; Deeley, C.; Como, P.G.; Brower, C.; Eapen, S.; Andresen, E.M.; Miller, B. Prevalence of tics in schoolchildren and association with placement in special education. Neurology 2001, 57, 1383-1388. [CrossRef]

50. Gadow, K.D.; Nolan, E.E.; Sprafkin, J.; Schwartz, J. Tics and psychiatric comorbidity in children and adolescents. Dev. Med. Child Neurol. 2002, 44, 330-338. [CrossRef]

51. Cubo, E.; Gabriel y Galán, J.M.; Villaverde, V.A.; Velasco, S.S.; Benito, V.D.; Macarrón, J.V.; Guevara, J.C.; Louis, E.D.; Benito-León, J. Prevalence of tics in schoolchildren in central Spain: A population-based study. Pediatr. Neurol. 2011, 45, 100-108. [CrossRef]

52. Alves, H.L.; Quagliato, E.M. The prevalence of tic disorders in children and adolescents in Brazil. Arq. Neuropsiquiatr. 2014, 72, 942-948. [CrossRef]

53. Hornsey, H.; Banerjee, S.; Zeitlin, H.; Robertson, M. The prevalence of Tourette syndrome in 13-14-year-olds in mainstream schools. J. Child Psychol. Psychiatry 2001, 42, 1035-1039. [CrossRef]

54. Khalifa, N.; von Knorring, A.L. Prevalence of tic disorders and Tourette syndrome in a Swedish school population. Dev. Med. Child Neurol. 2003, 45, 315-319. [CrossRef]

55. Mason, A.; Banerjee, S.; Eapen, V.; Zeitlin, H.; Robertson, M.M. The prevalence of Tourette syndrome in a mainstream school population. Dev. Med. Child Neurol. 1998, 40, 292-296.

56. Canitano, R.; Vivanti, G. Tics and Tourette syndrome in autism spectrum disorders. Autism 2007, 11, 19-28. [CrossRef]

57. Robakis, D. How much do we know about adult-onset primary tics? Prevalence, epidemiology, and clinical features. Tremor Other Hyperkinet. Mov. 2017, 7, 441. [CrossRef]

58. Jankovic, J.; Ashizawa, T. Tourettism associated with Huntington's disease. Mov. Disord. 1995, 10, 103-105. [CrossRef] [PubMed]

59. Mejia, N.I.; Jankovic, J. Secondary tics and tourettism. Braz. J. Psychiatry 2005, 27, 11-17. [CrossRef] [PubMed]

60. Factor, S.A.; Molho, E.S. Adult-onset tics associated with peripheral injury. Mov. Disord. 1997, 12, 1052-1055. [CrossRef] [PubMed]

61. Singer, C.; Sanchez-Ramos, J.; Weiner, W.J. A case of post-traumatic tic disorder. Mov. Disord. 1989, 4, 342-344. [CrossRef]

62. Chen, S.F.; Su, Y.C.; Wang, L.Y.; Hsu, C.Y.; Shen, Y.C. Tourette's syndrome is associated with an increased risk of traumatic brain injury: A nationwide population-Based cohort study. Parkinsonism Relat. Disord. 2019, 63, 88-93. [CrossRef] [PubMed]

63. Bansil, S.; Prakash, N.; Kaye, J.; Wrigley, S.; Manata, C.; Stevens-Haas, C.; Kurlan, R. Movement disorders after stroke in adults: A review. Tremor Other Hyperkinet. Mov. 2012, 2, tre-02-42-195-1. [CrossRef] 
64. Aquino, C.C.; Felício, A.C.; Godeiro-Junior, C.; Santos-Neto, D.; Pedroso, J.L.; Oliveira, A.S.; Silva, S.M.; Borges, V.; Ferraz, H.B. Tic disorder: An unusual presentation of neurotoxoplasmosis in a patient with AIDS. Case Rep. Neurol. 2010, 2, 145-149. [CrossRef] [PubMed]

65. Bharucha, K.J.; Sethi, K.D. Tardive tourettism after exposure to neuroleptic therapy. Mov. Disord. 1995, 10, 791-793. [CrossRef] [PubMed]

66. Kumar, R.; Lang, A.E. Tourette syndrome. Secondary tic disorders. Neurol. Clin. 1997, 15, 309-331. [CrossRef]

67. Pascual-Leone, A.; Dhuna, A. Cocaine-associated multifocal tics. Neurology 1990, 40, 999-1000. [CrossRef]

68. Peters, J.; Vijiaratnam, N.; Angus-Leppan, H. Tics induced by antiepileptic drugs: A pragmatic review. J. Neurol. 2021, 268, 321-336. [CrossRef]

69. Kim, D.D.; Barr, A.M.; Chung, Y.; Yuen, J.W.Y.; Etminan, M.; Carleton, B.C.; White, R.F.; Honer, W.G.; Procyshyn, R.M. Antipsychotic-associated symptoms of Tourette Syndrome: A systematic review. CNS Drugs 2018, 32, 917-938. [CrossRef] [PubMed]

70. Klawans, H.L.; Barr, A. Recurrence of childhood multiple tic in late adult life. Arch. Neurol. 1985, 42, 1079-1080. [CrossRef]

71. Albin, R.L.; Mink, J.W. Recent advances in Tourette syndrome research. Trends Neurosci. 2006, 29, 175-182. [CrossRef]

72. Augustine, F.; Singer, H.S. Merging the Pathophysiology and Pharmacotherapy of Tics. Tremor Other Hyperkinet. Mov. 2019, 8, 595. [CrossRef]

73. Church, J.A.; Fair, D.A.; Dosenbach, N.U.; Cohen, A.L.; Miezin, F.M.; Petersen, S.E.; Schlaggar, B.L. Control networks in paediatric Tourette syndrome show immature and anomalous patterns of functional connectivity. Brain 2009, 132, 225-238. [CrossRef]

74. Nielsen, A.N.; Gratton, C.; Church, J.A.; Dosenbach, N.U.F.; Black, K.J.; Petersen, S.E.; Schlaggar, B.L.; Greene, D.J. Atypical Functional Connectivity in Tourette Syndrome Differs Between Children and Adults. Biol. Psychiatry 2020, 87, 164-173. [CrossRef]

75. Peterson, B.S.; Thomas, P.; Kane, M.J.; Scahill, L.; Zhang, H.; Bronen, R.; King, R.A.; Leckman, J.F.; Staib, L. Basal Ganglia volumes in patients with Gilles de la Tourette syndrome. Arch. Gen. Psychiatry 2003, 60, 415-424. [CrossRef] [PubMed]

76. Singer, H.S. Tourette's syndrome: From behaviour to biology. Lancet Neurol. 2005, 4, 149-159. [CrossRef]

77. Yael, D.; Vinner, E.; Bar-Gad, I. Pathophysiology of tic disorders. Mov. Disord. 2015, 30, 1171-1178. [CrossRef]

78. Robertson, M.M.; Eapen, V.; Singer, H.S.; Martino, D.; Scharf, J.M.; Paschou, P.; Roessner, V.; Woods, D.W.; Hariz, M.; Mathews, C.A.; et al. Gilles de la Tourette syndrome. Nat. Rev. Dis. Primers 2017, 3, 16097. [CrossRef]

79. Leckman, J.F.; Dolnansky, E.S.; Hardin, M.T.; Clubb, M.; Walkup, J.T.; Stevenson, J.; Pauls, D.L. Perinatal factors in the expression of Tourette's syndrome: An exploratory study. J. Am. Acad. Child Adolesc. Psychiatry 1990, 29, 220-226. [CrossRef] [PubMed]

80. Burd, L.; Severud, R.; Klug, M.G.; Kerbeshian, J. Prenatal and perinatal risk factors for Tourette disorder. J. Perinat. Med. 1999, 27, 295-302. [CrossRef] [PubMed]

81. Chao, T.K.; Hu, J.; Pringsheim, T. Prenatal risk factors for Tourette Syndrome: A systematic review. BMC Pregnancy Childbirth 2014, 14, 53. [CrossRef]

82. Ayubi, E.; Mansori, K.; Doosti-Irani, A. Effect of maternal smoking during pregnancy on Tourette syndrome and chronic tic disorders among offspring: A systematic review and meta-analysis. Obstet. Gynecol. Sci. 2021, 64, 1-12. [CrossRef]

83. Mathews, C.A.; Scharf, J.M.; Miller, L.L.; Macdonald-Wallis, C.; Lawlor, D.A.; Ben-Shlomo, Y. Association between pre- and perinatal exposures and Tourette syndrome or chronic tic disorder in the ALSPAC cohort. Br. J. Psychiatry 2014, $204,40-45$. [CrossRef] [PubMed]

84. Leivonen, S.; Scharf, J.M.; Mathews, C.A.; Chudal, R.; Gyllenberg, D.; Sucksdorff, D.; Suominen, A.; Voutilainen, A.; Brown, A.S.; Sourander, A. Parental Psychopathology and Tourette Syndrome/Chronic Tic Disorder in Offspring: A Nationwide Case-Control Study. J. Am. Acad. Child Adolesc. Psychiatry 2017, 56, 297-303. [CrossRef] [PubMed]

85. Zhu, P.; Wu, M.; Huang, P.; Zhao, X.; Ji, X. Children from nuclear families with bad parental relationship could develop tic symptoms. Mol. Genet. Genom. Med. 2020, 8, e1286. [CrossRef] [PubMed]

86. Pauls, D.L.; Fernandez, T.V.; Mathews, C.A.; State, M.W.; Scharf, J.M. The Inheritance of Tourette Disorder: A review. J. Obs. Compuls. Relat. Disord. 2014, 3, 380-385. [CrossRef]

87. Pauls, D.L.; Leckman, J.F. The inheritance of Gilles de la Tourette's syndrome and associated behaviors. Evidence for autosomal dominant transmission. N. Engl. J. Med. 1986, 315, 993-997. [CrossRef]

88. Price, R.A.; Kidd, K.K.; Cohen, D.J.; Pauls, D.L.; Leckman, J.F. A twin study of Tourette syndrome. Arch. Gen. Psychiatry 1985, 42, 815-820. [CrossRef]

89. Hyde, T.M.; Aaronson, B.A.; Randolph, C.; Rickler, K.C.; Weinberger, D.R. Relationship of birth weight to the phenotypic expression of Gilles de la Tourette's syndrome in monozygotic twins. Neurology 1992, 42, 652-658. [CrossRef] [PubMed]

90. Davis, L.K.; Yu, D.; Keenan, C.L.; Gamazon, E.R.; Konkashbaev, A.I.; Derks, E.M.; Neale, B.M.; Yang, J.; Lee, S.H.; Evans, P.; et al. Partitioning the heritability of Tourette syndrome and obsessive compulsive disorder reveals differences in genetic architecture. PLoS Genet. 2013, 9, e1003864. [CrossRef]

91. Mataix-Cols, D.; Isomura, K.; Pérez-Vigil, A.; Chang, Z.; Rück, C.; Larsson, K.J.; Leckman, J.F.; Serlachius, E.; Larsson, H.; Lichtenstein, P. Familial Risks of Tourette Syndrome and Chronic Tic Disorders. A Population-Based Cohort Study. JAMA Psychiatry 2015, 72, 787-793. [CrossRef]

92. Georgitsi, M.; Willsey, A.J.; Mathews, C.A.; State, M.; Scharf, J.M.; Paschou, P. The Genetic Etiology of Tourette Syndrome: Large-Scale Collaborative Efforts on the Precipice of Discovery. Front. Neurosci. 2016, 10, 351. [CrossRef] 
93. Verkerk, A.J.; Mathews, C.A.; Joosse, M.; Eussen, B.H.; Heutink, P.; Oostra, B.A.; Tourette Syndrome Association International Consortium for Genetics. CNTNAP2 is disrupted in a family with Gilles de la Tourette syndrome and obsessive compulsive disorder. Genomics 2003, 82, 1-9. [CrossRef]

94. Lawson-Yuen, A.; Saldivar, J.S.; Sommer, S.; Picker, J. Familial deletion within NLGN4 associated with autism and Tourette syndrome. Eur. J. Hum. Genet. 2008, 16, 614-618. [CrossRef]

95. Abelson, J.F.; Kwan, K.Y.; O’Roak, B.J.; Baek, D.Y.; Stillman, A.A.; Morgan, T.M.; Mathews, C.A.; Pauls, D.L.; Rasin, M.R.; Gunel, M.; et al. Sequence variants in SLITRK1 are associated with Tourette's syndrome. Science 2005, 310, 317-320. [CrossRef]

96. Proenca, C.C.; Gao, K.P.; Shmelkov, S.V.; Rafii, S.; Lee, F.S. Slitrks as emerging candidate genes involved in neuropsychiatric disorders. Trends Neurosci. 2011, 34, 143-153. [CrossRef] [PubMed]

97. Ercan-Sencicek, A.G.; Stillman, A.A.; Ghosh, A.K.; Bilguvar, K.; O’Roak, B.J.; Mason, C.E.; Abbott, T.; Gupta, A.; King, R.A.; Pauls, D.L.; et al. L-histidine decarboxylase and Tourette's syndrome. N. Engl. J. Med. 2010, 362, 1901-1908. [CrossRef]

98. Patel, C.; Cooper-Charles, L.; McMullan, D.J.; Walker, J.M.; Davison, V.; Morton, J. Translocation breakpoint at 7q31 associated with tics: Further evidence for IMMP2L as a candidate gene for Tourette syndrome. Eur. J. Hum. Genet. 2011, 19, 634-639. [CrossRef]

99. Petek, E.; Windpassinger, C.; Vincent, J.B.; Cheung, J.; Boright, A.P.; Scherer, S.W.; Kroisel, P.M.; Wagner, K. Disruption of a novel gene (IMMP2L) by a breakpoint in 7q31 associated with Tourette syndrome. Am. J. Hum. Genet. 2001, 68, 848-858. [CrossRef]

100. George, S.K.; Jiao, Y.; Bishop, C.E.; Lu, B. Mitochondrial peptidase IMMP2L mutation causes early onset of age-associated disorders and impairs adult stem cell self-renewal. Aging Cell 2011, 10, 584-594. [CrossRef]

101. Bjerregaard, V.A.; Schönewolf-Greulich, B.; Juel Rasmussen, L.; Desler, C.; Tümer, Z. Mitochondrial Function in Gilles de la Tourette Syndrome Patients with and Without Intragenic IMMP2L Deletions. Front. Neurol. 2020, 11, 163. [CrossRef]

102. Sundaram, S.K.; Huq, A.M.; Wilson, B.J.; Chugani, H.T. Tourette syndrome is associated with recurrent exonic copy number variants. Neurology 2010, 74, 1583-1590. [CrossRef]

103. Huang, A.Y.; Yu, D.; Davis, L.K.; Sul, J.H.; Tsetsos, F.; Ramensky, V.; Zelaya, I.; Ramos, E.M.; Osiecki, L.; Chen, J.A.; et al. Rare Copy Number Variants in NRXN1 and CNTN6 Increase Risk for Tourette Syndrome. Neuron 2017, 94, 1101-1111.e7. [CrossRef]

104. Wang, S.; Mandell, J.D.; Kumar, Y.; Sun, N.; Morris, M.T.; Arbelaez, J.; Nasello, C.; Dong, S.; Duhn, C.; Zhao, X.; et al. De Novo Sequence and Copy Number Variants Are Strongly Associated with Tourette Disorder and Implicate Cell Polarity in Pathogenesis. Cell Rep. 2018, 24, 3441-3454.e12. [CrossRef] [PubMed]

105. Liu, S.; Tian, M.; He, F.; Li, J.; Xie, H.; Liu, W.; Zhang, Y.; Zhang, R.; Yi, M.; Che, F.; et al. Mutations in ASH1L confer susceptibility to Tourette syndrome. Mol. Psychiatry 2020, 25, 476-490. [CrossRef]

106. Depienne, C.; Ciura, S.; Trouillard, O.; Bouteiller, D.; Leitão, E.; Nava, C.; Keren, B.; Marie, Y.; Guegan, J.; Forlani, S.; et al. Association of Rare Genetic Variants in Opioid Receptors with Tourette Syndrome. Tremor Other Hyperkinet. Mov. $2019,9$. [CrossRef]

107. Liu, S.; Yu, X.; Xu, Q.; Cui, J.; Yi, M.; Zhang, X.; Ge, Y.; Ma, X. Support of positive association in family-based genetic analysis between COL27A1 and Tourette syndrome. Sci. Rep. 2015, 5, 12687. [CrossRef]

108. Scharf, J.M.; Yu, D.; Mathews, C.A.; Neale, B.M.; Stewart, S.E.; Fagerness, J.A.; Evans, P.; Gamazon, E.; Edlund, C.K.; Service, S.K.; et al. Genome-wide association study of Tourette's syndrome. Mol. Psychiatry 2013, 18, 721-728. [CrossRef]

109. Weidinger, E.; Krause, D.; Wildenauer, A.; Meyer, S.; Gruber, R.; Schwarz, M.J.; Müller, N. Impaired activation of the innate immune response to bacterial challenge in Tourette syndrome. World J. Biol. Psychiatry 2014, 15, 453-458. [CrossRef]

110. Leckman, J.F.; Katsovich, L.; Kawikova, I.; Lin, H.; Zhang, H.; Krönig, H.; Morshed, S.; Parveen, S.; Grantz, H.; Lombroso, P.J.; et al. Increased serum levels of interleukin-12 and tumor necrosis factor-alpha in Tourette's syndrome. Biol. Psychiatry 2005, 57, 667-673. [CrossRef]

111. Kawikova, I.; Leckman, J.F.; Kronig, H.; Katsovich, L.; Bessen, D.E.; Ghebremichael, M.; Bothwell, A.L. Decreased numbers of regulatory $\mathrm{T}$ cells suggest impaired immune tolerance in children with tourette syndrome: A preliminary study. Biol. Psychiatry 2007, 61, 273-278. [CrossRef]

112. Martino, D.; Church, A.J.; Defazio, G.; Dale, R.C.; Quinn, N.P.; Robertson, M.M.; Livrea, P.; Orth, M.; Giovannoni, G. Soluble adhesion molecules in Gilles de la Tourette's syndrome. J. Neurol. Sci. 2005, 234, 79-85. [CrossRef]

113. Bos-Veneman, N.G.; Olieman, R.; Tobiasova, Z.; Hoekstra, P.J.; Katsovich, L.; Bothwell, A.L.; Leckman, J.F.; Kawikova, I. Altered immunoglobulin profiles in children with Tourette syndrome. Brain Behav. Immun. 2011, 25, 532-538. [CrossRef] [PubMed]

114. Szejko, N.; Fremer, C.; Sühs, K.W.; Macul Ferreira de Barros, P.; Müller-Vahl, K.R. Intravenous Immunoglobulin Treatment Did Not Improve Tics in a Patient With Gilles de la Tourette Syndrome and Intrathecal Antibody Synthesis. Front. Neurol. 2020, 11, 110. [CrossRef] [PubMed]

115. Baumgaertel, C.; Skripuletz, T.; Kronenberg, J.; Stangel, M.; Schwenkenbecher, P.; Sinke, C.; Müller-Vahl, K.R.; Sühs, K.W. Immunity in Gilles de la Tourette-Syndrome: Results From a Cerebrospinal Fluid Study. Front. Neurol. 2019, 10, 732. [CrossRef]

116. Wenzel, C.; Wurster, U.; Müller-Vahl, K.R. Oligoclonal bands in cerebrospinal fluid in patients with Tourette's syndrome. Mov. Disord. 2011, 26, 343-346. [CrossRef]

117. Martino, D.; Zis, P.; Buttiglione, M. The role of immune mechanisms in Tourette syndrome. Brain Res. 2015, 1617, 126-143. [CrossRef] [PubMed]

118. Kondo, K.; Kabasawa, T. Improvement in Gilles de la Tourette syndrome after corticosteroid therapy. Ann. Neurol. $1978,4,387$. [CrossRef] 
119. Matarazzo, E.B. Tourette's Syndrome Treated with ACTH and Prednisone: Report of Two Cases. J. Child Adolesc. Psychopharmacol. 1992, 2, 215-226. [CrossRef] [PubMed]

120. Kiessling, L.S.; Marcotte, A.C.; Culpepper, L. Antineuronal antibodies in movement disorders. Pediatrics 1993, 92, 39-43. [PubMed]

121. Rizzo, R.; Gulisano, M.; Pavone, P.; Fogliani, F.; Robertson, M.M. Increased antistreptococcal antibody titers and anti-basal ganglia antibodies in patients with Tourette syndrome: Controlled cross-sectional study. J. Child Neurol. 2006, 21, 747-753. [CrossRef] [PubMed]

122. Singer, H.S.; Giuliano, J.D.; Hansen, B.H.; Hallett, J.J.; Laurino, J.P.; Benson, M.; Kiessling, L.S. Antibodies against human putamen in children with Tourette syndrome. Neurology 1998, 50, 1618-1624. [CrossRef]

123. Cardona, F.; Orefici, G. Group A streptococcal infections and tic disorders in an Italian pediatric population. J. Pediatr. 2001, 138, 71-75. [CrossRef]

124. Church, A.J.; Dale, R.C.; Lees, A.J.; Giovannoni, G.; Robertson, M.M. Tourette's syndrome: A cross sectional study to examine the PANDAS hypothesis. J. Neurol. Neurosurg. Psychiatry 2003, 74, 602-607. [CrossRef]

125. Swedo, S.E.; Leonard, H.L.; Rapoport, J.L. The pediatric autoimmune neuropsychiatric disorders associated with streptococcal infection (PANDAS) subgroup: Separating fact from fiction. Pediatrics 2004, 113, 907-911. [CrossRef]

126. Cunningham, M.W. Molecular Mimicry, Autoimmunity, and Infection: The Cross-Reactive Antigens of Group A Streptococci and their Sequelae. Microbiol. Spectr. 2019, 7. [CrossRef]

127. Morshed, S.A.; Parveen, S.; Leckman, J.F.; Mercadante, M.T.; Bittencourt Kiss, M.H.; Miguel, E.C.; Arman, A.; Yazgan, Y.; Fujii, T.; Paul, S.; et al. Antibodies against neural, nuclear, cytoskeletal, and streptococcal epitopes in children and adults with Tourette's syndrome, Sydenham's chorea, and autoimmune disorders. Biol. Psychiatry 2001, 50, 566-577. [CrossRef]

128. Singer, H.S.; Morris, C.M.; Williams, P.N.; Yoon, D.Y.; Hong, J.J.; Zimmerman, A.W. Antibrain antibodies in children with autism and their unaffected siblings. J. Neuroimmunol. 2006, 178, 149-155. [CrossRef]

129. Gilbert, D.L. Inflammation in Tic Disorders and Obsessive-Compulsive Disorder: Are PANS and PANDAS a Path Forward? J. Child Neurol. 2019, 34, 598-611. [CrossRef]

130. Singer, H.S. Autoantibody-Associated Movement Disorders in Children: Proven and Proposed. Semin. Pediatr. Neurol. 2017, 24, 168-179. [CrossRef] [PubMed]

131. Singer, H.S.; Giuliano, J.D.; Zimmerman, A.M.; Walkup, J.T. Infection: A stimulus for tic disorders. Pediatr. Neurol. 2000, 22, 380-383. [CrossRef]

132. Lougee, L.; Perlmutter, S.J.; Nicolson, R.; Garvey, M.A.; Swedo, S.E. Psychiatric disorders in first-degree relatives of children with pediatric autoimmune neuropsychiatric disorders associated with streptococcal infections (PANDAS). J. Am. Acad. Child Adolesc. Psychiatry 2000, 39, 1120-1126. [CrossRef] [PubMed]

133. Gilbert, D.L.; Mink, J.W.; Singer, H.S. A Pediatric Neurology Perspective on Pediatric Autoimmune Neuropsychiatric Disorder Associated with Streptococcal Infection and Pediatric Acute-Onset Neuropsychiatric Syndrome. J. Pediatr. 2018, 199, $243-251$. [CrossRef] [PubMed]

134. Gabbay, V.; Coffey, B.J.; Babb, J.S.; Meyer, L.; Wachtel, C.; Anam, S.; Rabinovitz, B. Pediatric autoimmune neuropsychiatric disorders associated with streptococcus: Comparison of diagnosis and treatment in the community and at a specialty clinic. Pediatrics 2008, 122, 273-278. [CrossRef] [PubMed]

135. Helm, C.E.; Blackwood, R.A. Pediatric Autoimmune Neuropsychiatric Disorder Associated with Streptococcal Infections (PANDAS): Experience at a Tertiary Referral Center. Tremor Other Hyperkinet. Mov. 2015, 5, 270. [CrossRef]

136. Singer, H.S.; Gilbert, D.L.; Wolf, D.S.; Mink, J.W.; Kurlan, R. Moving from PANDAS to CANS. J. Pediatr. 2012, $160,725-731$. [CrossRef] [PubMed]

137. Edmonson, M.B.; Farwell, K.R. Relationship between the clinical likelihood of group A streptococcal pharyngitis and the sensitivity of a rapid antigen-detection test in a pediatric practice. Pediatrics 2005, 115, 280-285. [CrossRef]

138. Gerber, M.A.; Randolph, M.F.; Mayo, D.R. The group A streptococcal carrier state. A reexamination. Am. J. Dis. Child. 1988, 142, 562-565. [CrossRef] [PubMed]

139. Johnson, D.R.; Kurlan, R.; Leckman, J.; Kaplan, E.L. The human immune response to streptococcal extracellular antigens: Clinical, diagnostic, and potential pathogenetic implications. Clin. Infect. Dis. 2010, 50, 481-490. [CrossRef]

140. Shimasaki, C.; Frye, R.E.; Trifiletti, R.; Cooperstock, M.; Kaplan, G.; Melamed, I.; Greenberg, R.; Katz, A.; Fier, E.; Kem, D.; et al. Evaluation of the Cunningham Panel ${ }^{\mathrm{TM}}$ in pediatric autoimmune neuropsychiatric disorder associated with streptococcal infection (PANDAS) and pediatric acute-onset neuropsychiatric syndrome (PANS): Changes in antineuronal antibody titers parallel changes in patient symptoms. J. Neuroimmunol. 2020, 339, 577138. [CrossRef]

141. Swedo, S.E.; Leckman, J.F.; Rose, N.R. From research subgroup to clinical syndrome: Modifying the PANDAS criteria to describe PANS (pediatric acute-onset neuropsychiatric syndrome). Pediatr. Therapeut. 2012, 2, 113. [CrossRef]

142. Hesselmark, E.; Bejerot, S. Biomarkers for diagnosis of Pediatric Acute Neuropsychiatric Syndrome (PANS)—Sensitivity and specificity of the Cunningham Panel. J. Neuroimmunol. 2017, 312, 31-37. [CrossRef]

143. Schrag, A.; Martino, D.; Apter, A.; Ball, J.; Bartolini, E.; Benaroya-Milshtein, N.; Buttiglione, M.; Cardona, F.; Creti, R.; Efstratiou, A.; et al. European Multicentre Tics in Children Studies (EMTICS): Protocol for two cohort studies to assess risk factors for tic onset and exacerbation in children and adolescents. Eur. Child Adolesc. Psychiatry 2019, 28, 91-109. [CrossRef] 
144. Baglioni, V.; Coutinho, E.; Menassa, D.A.; Giannoccaro, M.P.; Jacobson, L.; Buttiglione, M.; Petruzzelli, O.; Cardona, F.; Vincent, A.; EMTICS Collaborative Group. Antibodies to neuronal surface proteins in Tourette Syndrome: Lack of evidence in a European paediatric cohort. Brain Behav. Immun. 2019, 81, 665-669. [CrossRef]

145. Martino, D.; Schrag, A.; Anastasiou, Z.; Apter, A.; Benaroya-Milstein, N.; Buttiglione, M.; Cardona, F.; Creti, R.; Efstratiou, A.; Hedderly, T.; et al. Association of Group A Streptococcus Exposure and Exacerbations of Chronic Tic Disorders: A Multinational Prospective Cohort Study. Neurology 2021, 96, e1680-e1693. [CrossRef]

146. Thienemann, M.; Murphy, T.; Leckman, J.; Shaw, R.; Williams, K.; Kapphahn, C.; Frankovich, J.; Geller, D.; Bernstein, G.; Chang, K.; et al. Clinical Management of Pediatric Acute-Onset Neuropsychiatric Syndrome: Part I-Psychiatric and Behavioral Interventions. J. Child Adolesc. Psychopharmacol. 2017, 27, 566-573. [CrossRef]

147. Frankovich, J.; Swedo, S.; Murphy, T.; Dale, R.C.; Agalliu, D.; Williams, K.; Daines, M.; Hornig, M.; Chugani, H.; Sanger, T.; et al. Clinical management of pediatric acute-onset neuropsychiatric syndrome: Part II-Use of immunomodulatory therapies. J. Child Adolesc. Psychopharmacol. 2017, 27, 574-593. [CrossRef]

148. Hoekstra, P.J.; Minderaa, R.B.; Kallenberg, C.G. Lack of effect of intravenous immunoglobulins on tics: A double-blind placebocontrolled study. J. Clin. Psychiatry 2004, 65, 537-542. [CrossRef]

149. Williams, K.A.; Swedo, S.E.; Farmer, C.A.; Grantz, H.; Grant, P.J.; D’Souza, P.; Hommer, R.; Katsovich, L.; King, R.A.; Leckman, J.F. Randomized, Controlled Trial of Intravenous Immunoglobulin for Pediatric Autoimmune Neuropsychiatric Disorders Associated With Streptococcal Infections. J. Am. Acad. Child Adolesc. Psychiatry 2016, 55, 860-867.e2. [CrossRef] [PubMed]

150. Perlmutter, S.J.; Leitman, S.F.; Garvey, M.A.; Hamburger, S.; Feldman, E.; Leonard, H.L.; Swedo, S.E. Therapeutic plasma exchange and intravenous immunoglobulin for obsessive-compulsive disorder and tic disorders in childhood. Lancet 1999, 354, 1153-1158. [CrossRef]

151. PANDAS/PANS and Tourette Syndrome (Disorder). Available online: https://tourette.org/research-medical/pandas-pans-andtourette-syndrome-disorder/ (accessed on 26 May 2021).

152. Stafford, M.; Cavanna, A.E. Prevalence and clinical correlates of self-injurious behavior in Tourette syndrome. Neurosci. Biobehav. Rev. 2020, 113, 299-307. [CrossRef] [PubMed]

153. Eddy, C.M.; Rizzo, R.; Gulisano, M.; Agodi, A.; Barchitta, M.; Calì, P.; Robertson, M.M.; Cavanna, A.E. Quality of life in young people with Tourette syndrome: A controlled study. J. Neurol. 2011, 258, 291-301. [CrossRef] [PubMed]

154. Ghosh, D.; Rajan, P.V.; Das, D.; Datta, P.; Rothner, A.D.; Erenberg, G. Sleep disorders in children with Tourette syndrome. Pediatr. Neurol. 2014, 51, 31-35. [CrossRef] [PubMed]

155. Kwak, C.; Vuong, K.D.; Jankovic, J. Migraine headache in patients with Tourette syndrome. Arch. Neurol. 2003, 60, 1595-1598. [CrossRef]

156. Marwitz, L.; Pringsheim, T. Clinical Utility of Screening for Anxiety and Depression in Children with Tourette Syndrome. J. Can. Acad. Child Adolesc. Psychiatry 2018, 27, 15-21.

157. Piedad, J.C.; Cavanna, A.E. Depression in Tourette syndrome: A controlled and comparison study. J. Neurol. Sci. 2016, 364, 128-132. [CrossRef] [PubMed]

158. Robertson, M.M. A personal 35 year perspective on Gilles de la Tourette syndrome: Prevalence, phenomenology, comorbidities, and coexistent psychopathologies. Lancet Psychiatry 2015, 2, 68-87. [CrossRef]

159. Freeman, R.D.; Fast, D.K.; Burd, L.; Kerbeshian, J.; Robertson, M.M.; Sandor, P. An international perspective on Tourette syndrome: Selected findings from 3500 individuals in 22 countries. Dev. Med. Child Neurol. 2000, 42, 436-447. [CrossRef] [PubMed]

160. Hirschtritt, M.E.; Lee, P.C.; Pauls, D.L.; Dion, Y.; Grados, M.A.; Illmann, C.; King, R.A.; Sandor, P.; McMahon, W.M.; Lyon, G.J.; et al. Lifetime prevalence, age of risk, and genetic relationships of comorbid psychiatric disorders in Tourette syndrome. JAMA Psychiatry 2015, 72, 325-333. [CrossRef]

161. Brainstorm Consortium; Anttila, V.; Bulik-Sullivan, B.; Finucane, H.K.; Walters, R.K.; Bras, J.; Duncan, L.; Escott-Price, V.; Falcone, G.J.; Gormley, P.; et al. Analysis of shared heritability in common disorders of the brain. Science 2018, 360. [CrossRef]

162. Hirschtritt, M.E.; Darrow, S.M.; Illmann, C.; Osiecki, L.; Grados, M.; Sandor, P.; Dion, Y.; King, R.A.; Pauls, D.; Budman, C.L.; et al. Genetic and phenotypic overlap of specific obsessive-compulsive and attention-deficit/hyperactive subtypes with Tourette syndrome. Psychol. Med. 2018, 48, 279-293. [CrossRef] [PubMed]

163. Meier, S.M.; Dalsgaard, S.; Mortensen, P.B.; Leckman, J.F.; Plessen, K.J. Mortality risk in a nationwide cohort of individuals with tic disorders and with tourette syndrome. Mov. Disord. 2017, 32, 605-609. [CrossRef] [PubMed]

164. Lowe, T.L.; Capriotti, M.R.; McBurnett, K. Long-Term Follow-up of Patients with Tourette's Syndrome. Mov. Disord. Clin. Pract. 2018, 6, 40-45. [CrossRef] [PubMed]

165. Bernard, B.A.; Stebbins, G.T.; Siegel, S.; Schultz, T.M.; Hays, C.; Morrissey, M.J.; Leurgans, S.; Goetz, C.G. Determinants of quality of life in children with Gilles de la Tourette syndrome. Mov. Disord. 2009, 24, 1070-1073. [CrossRef]

166. Carter, A.S.; O’Donnell, D.A.; Schultz, R.T.; Scahill, L.; Leckman, J.F.; Pauls, D.L. Social and emotional adjustment in children affected with Gilles de la Tourette's syndrome: Associations with ADHD and family functioning. Attention Deficit Hyperactivity Disorder. J. Child Psychol. Psychiatry 2000, 41, 215-223. [CrossRef]

167. Stiede, J.T.; Alexander, J.R.; Wellen, B.; Bauer, C.C.; Himle, M.B.; Mouton-Odum, S.; Woods, D.W. Differentiating tic-related from non-tic-related impairment in children with persistent tic disorders. Compr. Psychiatry 2018, 87, 38-45. [CrossRef]

168. Comings, D.E.; Comings, B.G. A controlled study of Tourette syndrome. I. Attention-deficit disorder, learning disorders, and school problems. Am. J. Hum. Genet. 1987, 41, 701-741. [PubMed] 
169. Spencer, T.; Biederman, J.; Harding, M.; O’Donnell, D.; Wilens, T.; Faraone, S.; Coffey, B.; Geller, D. Disentangling the overlap between Tourette's disorder and ADHD. J. Child Psychol. Psychiatry 1998, 39, 1037-1044. [CrossRef]

170. Sukhodolsky, D.G.; Scahill, L.; Zhang, H.; Peterson, B.S.; King, R.A.; Lombroso, P.J.; Katsovich, L.; Findley, D.; Leckman, J.F. Disruptive behavior in children with Tourette's syndrome: Association with ADHD comorbidity, tic severity, and functional impairment. J. Am. Acad. Child Adolesc. Psychiatry 2003, 42, 98-105. [CrossRef]

171. Termine, C.; Luoni, C.; Fontolan, S.; Selvini, C.; Perego, L.; Pavone, F.; Rossi, G.; Balottin, U.; Cavanna, A.E. Impact of co-morbid attention-deficit and hyperactivity disorder on cognitive function in male children with Tourette syndrome: A controlled study. Psychiatry Res. 2016, 243, 263-267. [CrossRef] [PubMed]

172. Mathews, C.A.; Grados, M.A. Familiality of Tourette syndrome, obsessive-compulsive disorder, and attention-deficit/hyperactivity disorder: Heritability analysis in a large sib-pair sample. J. Am. Acad. Child Adolesc. Psychiatry 2011, 50, 46-54. [CrossRef] [PubMed]

173. Stewart, S.E.; Illmann, C.; Geller, D.A.; Leckman, J.F.; King, R.; Pauls, D.L. A controlled family study of attentiondeficit/hyperactivity disorder and Tourette's disorder. J. Am. Acad. Child Adolesc. Psychiatry 2006, 45, 1354-1362. [CrossRef]

174. Kurlan, R. Methylphenidate to treat ADHD is not contraindicated in children with tics. Mov. Disord. 2002, 17, 5-6. [CrossRef]

175. ADHD Medications and Tics. Available online: https:/ / tics.wustl.edu/adhd-medications-and-tics/ (accessed on 26 May 2021).

176. Spencer, T.; Biederman, M.; Coffey, B.; Geller, D.; Wilens, T.; Faraone, S. The 4-year course of tic disorders in boys with attention-deficit/hyperactivity disorder. Arch. Gen. Psychiatry 1999, 56, 842-847. [CrossRef]

177. Law, S.F.; Schachar, R.J. Do typical clinical doses of methylphenidate cause tics in children treated for attention-deficit hyperactivity disorder? J. Am. Acad. Child Adolesc. Psychiatry 1999, 38, 944-951. [CrossRef]

178. Tourette's Syndrome Study Group. Treatment of ADHD in children with tics: A randomized controlled trial. Neurology 2002, 58, 527-536. [CrossRef] [PubMed]

179. Bloch, M.H.; Panza, K.E.; Landeros-Weisenberger, A.; Leckman, J.F. Meta-analysis: Treatment of attention-deficit/hyperactivity disorder in children with comorbid tic disorders. J. Am. Acad. Child Adolesc. Psychiatry 2009, 48, 884-893. [CrossRef]

180. Lyon, G.J.; Samar, S.M.; Conelea, C.; Trujillo, M.R.; Lipinski, C.M.; Bauer, C.C.; Brandt, B.C.; Kemp, J.J.; Lawrence, Z.E.; Howard, J.; et al. Testing tic suppression: Comparing the effects of dexmethylphenidate to no medication in children and adolescents with attention-deficit/hyperactivity disorder and Tourette's disorder. J. Child Adolesc. Psychopharmacol. 2010, 20, 283-289. [CrossRef]

181. Castellanos, F.X.; Giedd, J.N.; Elia, J.; Marsh, W.; Ritchie, G.F.; Hamburger, S.D.; Rapoport, J.L. Controlled stimulant treatment of ADHD and comorbid Tourette's syndrome: Effects of stimulant and dose. J. Am. Acad. Child Adolesc. Psychiatry 1997, 36, 589-596. [CrossRef] [PubMed]

182. Lombroso, P.J.; Scahill, L. Tourette syndrome and obsessive-compulsive disorder. Brain Dev. 2008, 30, 231-237. [CrossRef]

183. Adam, Y.; Meinlschmidt, G.; Gloster, A.T.; Lieb, R. Obsessive-compulsive disorder in the community: 12-month prevalence, comorbidity and impairment. Soc. Psychiatry Psychiatr. Epidemiol. 2012, 47, 339-349. [CrossRef] [PubMed]

184. Ruscio, A.M.; Stein, D.J.; Chiu, W.T.; Kessler, R.C. The epidemiology of obsessive-compulsive disorder in the National Comorbidity Survey Replication. Mol. Psychiatry 2010, 15, 53-63. [CrossRef]

185. Ferrão, Y.A.; Miguel, E.; Stein, D.J. Tourette's syndrome, trichotillomania, and obsessive-compulsive disorder: How closely are they related? Psychiatry Res. 2009, 170, 32-42. [CrossRef]

186. Holzer, J.C.; Goodman, W.K.; McDougle, C.J.; Baer, L.; Boyarsky, B.K.; Leckman, J.F.; Price, L.H. Obsessive-compulsive disorder with and without a chronic tic disorder. A comparison of symptoms in 70 patients. Br. J. Psychiatry 1994, 164, 469-473. [CrossRef] [PubMed]

187. Browne, H.A.; Hansen, S.N.; Buxbaum, J.D.; Gair, S.L.; Nissen, J.B.; Nikolajsen, K.H.; Schendel, D.E.; Reichenberg, A.; Parner, E.T.; Grice, D.E. Familial clustering of tic disorders and obsessive-compulsive disorder. JAMA Psychiatry 2015, 72, 359-366. [CrossRef]

188. Yu, D.; Mathews, C.A.; Scharf, J.M.; Neale, B.M.; Davis, L.K.; Gamazon, E.R.; Derks, E.M.; Evans, P.; Edlund, C.K.; Crane, J.; et al. Cross-disorder genome-wide analyses suggest a complex genetic relationship between Tourette's syndrome and OCD. Am. J. Psychiatry 2015, 172, 82-93. [CrossRef]

189. Worbe, Y.; Mallet, L.; Golmard, J.L.; Béhar, C.; Durif, F.; Jalenques, I.; Damier, P.; Derkinderen, P.; Pollak, P.; Anheim, M.; et al. Repetitive behaviours in patients with Gilles de la Tourette syndrome: Tics, compulsions, or both? PLoS ONE 2010, 5, e12959. [CrossRef] [PubMed]

190. Eapen, V.; Robertson, M.M.; Alsobrook, J.P., 2nd; Pauls, D.L. Obsessive compulsive symptoms in Gilles de la Tourette syndrome and obsessive compulsive disorder: Differences by diagnosis and family history. Am. J. Med. Genet. 1997, 74, 432-438. [CrossRef]

191. Leckman, J.F.; Grice, D.E.; Barr, L.C.; de Vries, A.L.; Martin, C.; Cohen, D.J.; McDougle, C.J.; Goodman, W.K.; Rasmussen, S.A. Tic-related vs. non-tic-related obsessive compulsive disorder. Anxiety 1994, 1, 208-215.

192. Leckman, J.F.; Walker, D.E.; Goodman, W.K.; Pauls, D.L.; Cohen, D.J. “Just right” perceptions associated with compulsive behavior in Tourette's syndrome. Am. J. Psychiatry 1994, 151, 675-680. [CrossRef]

193. Lamothe, H.; Baleyte, J.M.; Mallet, L.; Pelissolo, A. Trichotillomania is more related to Tourette disorder than to obsessivecompulsive disorder. Braz. J. Psychiatry 2020, 42, 87-104. [CrossRef] [PubMed]

194. Leckman, J.F.; Riddle, M.A.; Hardin, M.T.; Ort, S.I.; Swartz, K.L.; Stevenson, J.; Cohen, D.J. The Yale Global Tic Severity Scale: Initial testing of a clinician-rated scale of tic severity. J. Am. Acad. Child Adolesc. Psychiatry 1989, 28, 566-573. [CrossRef]

195. Rizzo, R.; Gulisano, M.; Martino, D.; Robertson, M.M. Gilles de la Tourette Syndrome, Depression, Depressive Illness, and Correlates in a Child and Adolescent Population. J. Child Adolesc. Psychopharmacol. 2017, 27, 243-249. [CrossRef] 
196. Johnco, C.; McGuire, J.F.; McBride, N.M.; Murphy, T.K.; Lewin, A.B.; Storch, E.A. Suicidal ideation in youth with tic disorders. J. Affect. Disord. 2016, 200, 204-211. [CrossRef]

197. Storch, E.A.; Hanks, C.E.; Mink, J.W.; McGuire, J.F.; Adams, H.R.; Augustine, E.F.; Vierhile, A.; Thatcher, A.; Bitsko, R.; Lewin, A.B.; et al. Suicidal thoughts and behaviors in children and adolescents with chronic tic disorders. Depress. Anxiety 2015, 32, 744-753. [CrossRef] [PubMed]

198. Fernández de la Cruz, L.; Rydell, M.; Runeson, B.; Brander, G.; Rück, C.; D’Onofrio, B.M.; Larsson, H.; Lichtenstein, P.; Mataix-Cols, D. Suicide in Tourette's and Chronic Tic Disorders. Biol. Psychiatry 2017, 82, 111-118. [CrossRef] [PubMed]

199. Rickards, H.; Robertson, M.M. Vomiting and retching in Gilles de la Tourette syndrome: A report of ten cases and a review of the literature. Mov. Disord. 1997, 12, 531-535. [CrossRef]

200. Budman, C.L.; Rockmore, L.; Stokes, J.; Sossin, M. Clinical phenomenology of episodic rage in children with Tourette syndrome. J. Psychosom. Res. 2003, 55, 59-65. [CrossRef]

201. Budman, C.L.; Bruun, R.D.; Park, K.S.; Olson, M.E. Rage attacks in children and adolescents with Tourette's disorder: A pilot study. J. Clin. Psychiatry 1998, 59, 576-580. [CrossRef]

202. Mathews, C.A.; Waller, J.; Glidden, D.; Lowe, T.L.; Herrera, L.D.; Budman, C.L.; Erenberg, G.; Naarden, A.; Bruun, R.D.; Freimer, N.B.; et al. Self injurious behaviour in Tourette syndrome: Correlates with impulsivity and impulse control. J. Neurol. Neurosurg. Psychiatry 2004, 75, 1149-1155. [CrossRef]

203. Eapen, V.; Robertson, M.M. Clinical correlates of Tourette's disorder across cultures: A comparative study between the United Arab Emirates and the United Kingdom. Prim. Care Companion J. Clin. Psychiatry 2008, 10, 103-107. [CrossRef] [PubMed]

204. Cox, J.H.; Nahar, A.; Termine, C.; Agosti, M.; Balottin, U.; Seri, S.; Cavanna, A.E. Social stigma and self-perception in adolescents with tourette syndrome. Adolesc. Health Med. Ther. 2019, 10, 75-82. [CrossRef]

205. Silvestri, P.R.; Baglioni, V.; Cardona, F.; Cavanna, A.E. Self-concept and self-esteem in patients with chronic tic disorders: A systematic literature review. Eur. J. Paediatr. Neurol. 2018, 22, 749-756. [CrossRef] [PubMed]

206. Cavanna, A.E.; Robertson, M.M.; Critchley, H.D. Schizotypal personality traits in Gilles de la Tourette syndrome. Acta Neurol. Scand. 2007, 116, 385-391. [CrossRef] [PubMed]

207. Jankovic, J.; Kwak, C.; Frankoff, R. Tourette's syndrome and the law. J. Neuropsychiatry Clin. Neurosci. 2006, 18, 86-95. [CrossRef] [PubMed]

208. Jankovic, J.; Rohaidy, H. Motor, behavioral and pharmacologic findings in Tourette's syndrome. Can. J. Neurol. Sci. 1987, 14 (Suppl. S3), 541-546. [CrossRef] [PubMed]

209. Lee, W.T.; Huang, H.L.; Wong, L.C.; Weng, W.C.; Vasylenko, T.; Jong, Y.J.; Lin, W.S.; Ho, S.Y. Tourette Syndrome as an Independent Risk Factor for Subsequent Sleep Disorders in Children: A Nationwide Population-Based Case-Control Study. Sleep 2017, 40. [CrossRef] [PubMed]

210. Ricketts, E.J.; Rozenman, M.; Choy, C.; Goldberg, H.B.; Kim, J.S.; Colwell, C.S.; McCracken, J.T.; Piacentini, J. Sleep Sufficiency in Pediatric and Adolescent Tourette's Disorder: National Survey of Children's Health. J. Dev. Behav. Pediatr. 2018, $39,72-76$. [CrossRef]

211. Kirov, R.; Kinkelbur, J.; Banaschewski, T.; Rothenberger, A. Sleep patterns in children with attention-deficit/hyperactivity disorder, tic disorder, and comorbidity. J. Child Psychol. Psychiatry 2007, 48, 561-570. [CrossRef]

212. Mol Debes, N.M.; Hjalgrim, H.; Skov, L. Validation of the presence of comorbidities in a Danish clinical cohort of children with Tourette syndrome. J. Child Neurol. 2008, 23, 1017-1027. [CrossRef]

213. Ghosh, D.; Rajan, P.V.; Das, D.; Datta, P.; Rothner, A.D.; Erenberg, G. Headache in children with Tourette syndrome. J. Pediatr. 2012, 161, 303-307.e6. [CrossRef]

214. Barabas, G.; Matthews, W.S.; Ferrari, M. Tourette's syndrome and migraine. Arch. Neurol. 1984, 41, 871-872. [CrossRef]

215. Channon, S.; Pratt, P.; Robertson, M.M. Executive function, memory, and learning in Tourette's syndrome. Neuropsychology 2003, 17, 247-254. [CrossRef] [PubMed]

216. Brand, N.; Geenen, R.; Oudenhoven, M.; Lindenborn, B.; van der Ree, A.; Cohen-Kettenis, P.; Buitelaar, J.K. Brief report: Cognitive functioning in children with Tourette's syndrome with and without comorbid ADHD. J. Pediatr. Psychol. 2002, 27, 203-208. [CrossRef]

217. Singer, H.S.; Schuerholz, L.J.; Denckla, M.B. Learning difficulties in children with Tourette syndrome. J. Child Neurol. 1995, 10 (Suppl. S1), S58-S61. [CrossRef]

218. Schuerholz, L.J.; Baumgardner, T.L.; Singer, H.S.; Reiss, A.L.; Denckla, M.B. Neuropsychological status of children with Tourette's syndrome with and without attention deficit hyperactivity disorder. Neurology 1996, 46, 958-965. [CrossRef]

219. Pérez-Vigil, A.; Fernández de la Cruz, L.; Brander, G.; Isomura, K.; Jangmo, A.; Kuja-Halkola, R.; Hesselmark, E.; D’Onofrio, B.M.; Larsson, H.; Mataix-Cols, D. Association of Tourette Syndrome and Chronic Tic Disorders with Objective Indicators of Educational Attainment: A Population-Based Sibling Comparison Study. JAMA Neurol. 2018, 75, 1098-1105. [CrossRef] [PubMed]

220. Martino, D.; Pringsheim, T.M.; Cavanna, A.E.; Colosimo, C.; Hartmann, A.; Leckman, J.F.; Luo, S.; Munchau, A.; Goetz, C.G.; Stebbins, G.T.; et al. Systematic review of severity scales and screening instruments for tics: Critique and recommendations. Mov. Disord. 2017, 32, 467-473. [CrossRef]

221. Pringsheim, T.; Okun, M.S.; Müller-Vahl, K.; Martino, D.; Jankovic, J.; Cavanna, A.E.; Woods, D.W.; Robinson, M.; Jarvie, E.; Roessner, V.; et al. Practice guideline recommendations summary: Treatment of tics in people with Tourette syndrome and chronic tic disorders. Neurology 2019, 92, 896-906. [CrossRef] 
222. Specht, M.W.; Nicotra, C.M.; Kelly, L.M.; Woods, D.W.; Ricketts, E.J.; Perry-Parrish, C.; Reynolds, E.; Hankinson, J.; Grados, M.A.; Ostrander, R.S.; et al. A Comparison of Urge Intensity and the Probability of Tic Completion during Tic Freely and Tic Suppression Conditions. Behav. Modif. 2014, 38, 297-318. [CrossRef]

223. Verdellen, C.W.; Keijsers, G.P.; Cath, D.C.; Hoogduin, C.A. Exposure with response prevention versus habit reversal in Tourettes's syndrome: A controlled study. Behav. Res. Ther. 2004, 42, 501-511. [CrossRef]

224. Hoogduin, K.; Verdellen, C.; Cath, D. Exposure and Response Prevention in the Treatment of Gilles de la Tourette's Syndrome: Four Case Studies. Clin. Psychol. Psychother. 1997, 4, 125-135. [CrossRef]

225. Piacentini, J.; Woods, D.W.; Scahill, L.; Wilhelm, S.; Peterson, A.L.; Chang, S.; Ginsburg, G.S.; Deckersbach, T.; Dziura, J.; Levi-Pearl, S.; et al. Behavior therapy for children with Tourette disorder: A randomized controlled trial. JAMA 2010, 303, 1929-1937. [CrossRef] [PubMed]

226. Himle, M.B.; Woods, D.W.; Piacentini, J.C.; Walkup, J.T. Brief review of habit reversal training for Tourette syndrome. J. Child Neurol. 2006, 21, 719-725. [CrossRef] [PubMed]

227. Sukhodolsky, D.G.; Woods, D.W.; Piacentini, J.; Wilhelm, S.; Peterson, A.L.; Katsovich, L.; Dziura, J.; Walkup, J.T.; Scahill, L. Moderators and predictors of response to behavior therapy for tics in Tourette syndrome. Neurology 2017, 88, 1029-1036. [CrossRef]

228. Woods, D.W.; Piacentini, J.C.; Scahill, L.; Peterson, A.L.; Wilhelm, S.; Chang, S.; Deckersbach, T.; McGuire, J.; Specht, M.; Conelea, C.A.; et al. Behavior therapy for tics in children: Acute and long-term effects on psychiatric and psychosocial functioning. J. Child Neurol. 2011, 26, 858-865. [CrossRef]

229. Espil, F.M. A Long Term Follow up to a Randomized Controlled Trial of Comprehensive Behavioral Intervention for Tics. Ph.D. Dissertation, The University of Wisconsin-Milwaukee, Milwaukee, WI, USA, 2015. Available online: https://dc.uwm.edu/etd/ 996/ (accessed on 3 June 2021).

230. Fründt, O.; Woods, D.; Ganos, C. Behavioral therapy for Tourette syndrome and chronic tic disorders. Neurol. Clin. Pract. 2017, 7, 148-156. [CrossRef]

231. Wilhelm, S.; Peterson, A.L.; Piacentini, J.; Woods, D.W.; Deckersbach, T.; Sukhodolsky, D.G.; Chang, S.; Liu, H.; Dziura, J.; Walkup, J.T.; et al. Randomized trial of behavior therapy for adults with Tourette syndrome. Arch. Gen. Psychiatry 2012, 69, 795-803. [CrossRef]

232. Conelea, C.A.; Wellen, B.C.M. Tic Treatment Goes Tech: A Review of TicHelper.com. Cogn. Behav. Pract. 2017, $24,374-381$. [CrossRef] [PubMed]

233. Black, J.K.; Black, K.J. Software for web-based tic suppression training. F1000Research 2017, 6, 2150. [CrossRef]

234. Andrén, P.; Aspvall, K.; Fernández de la Cruz, L.; Wiktor, P.; Romano, S.; Andersson, E.; Murphy, T.; Isomura, K.; Serlachius, E.; Mataix-Cols, D. Therapist-guided and parent-guided internet-delivered behaviour therapy for paediatric Tourette's disorder: A pilot randomised controlled trial with long-term follow-up. BMJ Open 2019, 9, e024685. [CrossRef] [PubMed]

235. Nissen, J.B.; Kaergaard, M.; Laursen, L.; Parner, E.; Thomsen, P.H. Combined habit reversal training and exposure response prevention in a group setting compared to individual training: A randomized controlled clinical trial. Eur. Child Adolesc. Psychiatry 2019, 28, 57-68. [CrossRef]

236. Kompoliti, K.; Fan, W.; Leurgans, S. Complementary and alternative medicine use in Gilles de la Tourette syndrome. Mov. Disord. 2009, 24, 2015-2019. [CrossRef]

237. Kumar, A.; Duda, L.; Mainali, G.; Asghar, S.; Byler, D. A Comprehensive Review of Tourette Syndrome and Complementary Alternative Medicine. Curr. Dev. Disord. Rep. 2018, 5, 95-100. [CrossRef] [PubMed]

238. Yu, J.; Ye, Y.; Liu, J.; Wang, Y.; Peng, W.; Liu, Z. Acupuncture for Tourette Syndrome: A Systematic Review. Evid. Based Complement. Altern. Med. 2016, 2016, 1834646. [CrossRef]

239. Pringsheim, T.; Holler-Managan, Y.; Okun, M.S.; Jankovic, J.; Piacentini, J.; Cavanna, A.E.; Martino, D.; Müller-Vahl, K.; Woods, D.W.; Robinson, M.; et al. Comprehensive systematic review summary: Treatment of tics in people with Tourette syndrome and chronic tic disorders. Neurology 2019, 92, 907-915. [CrossRef]

240. Jankovic, J. Treatment of tics associated with Tourette syndrome. J. Neural Transm. 2020, 127, 843-850. [CrossRef]

241. Quezada, J.; Coffman, K.A. Current Approaches and New Developments in the Pharmacological Management of Tourette Syndrome. CNS Drugs 2018, 32, 33-45. [CrossRef]

242. Singer, H.S. Tics and Tourette Syndrome. Continuum 2019, 25, 936-958. [CrossRef]

243. Eddy, C.M.; Rickards, H.E.; Cavanna, A.E. Treatment strategies for tics in Tourette syndrome. Ther. Adv. Neurol. Disord. 2011, 4, 25-45. [CrossRef] [PubMed]

244. Kollins, S.H.; Jain, R.; Brams, M.; Segal, S.; Findling, R.L.; Wigal, S.B.; Khayrallah, M. Clonidine extended-release tablets as add-on therapy to psychostimulants in children and adolescents with ADHD. Pediatrics 2011, 127, e1406-e1413. [CrossRef] [PubMed]

245. Ming, X.; Mulvey, M.; Mohanty, S.; Patel, V. Safety and efficacy of clonidine and clonidine extended-release in the treatment of children and adolescents with attention deficit and hyperactivity disorders. Adolesc. Health Med. Ther. 2011, 2, 105-112. [CrossRef] [PubMed]

246. Du, Y.S.; Li, H.F.; Vance, A.; Zhong, Y.Q.; Jiao, F.Y.; Wang, H.M.; Wang, M.J.; Su, L.Y.; Yu, D.L.; Ma, S.W.; et al. Randomized double-blind multicentre placebo-controlled clinical trial of the clonidine adhesive patch for the treatment of tic disorders. Aust. N. Z. J. Psychiatry 2008, 42, 807-813. [CrossRef] 
247. Pringsheim, T.; Doja, A.; Gorman, D.; McKinlay, D.; Day, L.; Billinghurst, L.; Carroll, A.; Dion, Y.; Luscombe, S.; Steeves, T.; et al. Canadian guidelines for the evidence-based treatment of tic disorders: Pharmacotherapy. Can. J. Psychiatry 2012, 57, 133-143. [CrossRef]

248. Roessner, V.; Plessen, K.J.; Rothenberger, A.; Ludolph, A.G.; Rizzo, R.; Skov, L.; Strand, G.; Stern, J.S.; Termine, C.; Hoekstra, P.J.; et al. European clinical guidelines for Tourette syndrome and other tic disorders. Part II: Pharmacological treatment. Eur. Child Adolesc. Psychiatry 2011, 20, 173-196. [CrossRef]

249. Qasaymeh, M.M.; Mink, J.W. New treatments for tic disorders. Curr. Treat. Options Neurol. 2006, 8, 465-473. [CrossRef]

250. Gutgesell, H.; Atkins, D.; Barst, R.; Buck, M.; Franklin, W.; Humes, R.; Ringel, R.; Shaddy, R.; Taubert, K.A. Cardiovascular monitoring of children and adolescents receiving psychotropic drugs: A statement for healthcare professionals from the Committee on Congenital Cardiac Defects, Council on Cardiovascular Disease in the Young, American Heart Association. Circulation 1999, 99, 979-982. [CrossRef]

251. Boon-yasidhi, V.; Kim, Y.S.; Scahill, L. An open-label, prospective study of guanfacine in children with ADHD and tic disorders. J. Med. Assoc. Thai. 2005, 88 (Suppl. 8), S156-S162. [PubMed]

252. Chappell, P.B.; Riddle, M.A.; Scahill, L.; Lynch, K.A.; Schultz, R.; Arnsten, A.; Leckman, J.F.; Cohen, D.J. Guanfacine treatment of comorbid attention-deficit hyperactivity disorder and Tourette's syndrome: Preliminary clinical experience. J. Am. Acad. Child Adolesc. Psychiatry 1995, 34, 1140-1146. [CrossRef]

253. Scahill, L.; Chappell, P.B.; Kim, Y.S.; Schultz, R.T.; Katsovich, L.; Shepherd, E.; Arnsten, A.F.; Cohen, D.J.; Leckman, J.F. A placebocontrolled study of guanfacine in the treatment of children with tic disorders and attention deficit hyperactivity disorder. Am. J. Psychiatry 2001, 158, 1067-1074. [CrossRef]

254. Murphy, T.K.; Fernandez, T.V.; Coffey, B.J.; Rahman, O.; Gavaletz, A.; Hanks, C.E.; Tillberg, C.S.; Gomez, L.I.; Sukhodolsky, D.G.; Katsovich, L.; et al. Extended-Release Guanfacine Does Not Show a Large Effect on Tic Severity in Children with Chronic Tic Disorders. J. Child Adolesc. Psychopharmacol. 2017, 27, 762-770. [CrossRef]

255. Sharma, A.; Couture, J. A review of the pathophysiology, etiology, and treatment of attention-deficit hyperactivity disorder (ADHD). Ann. Pharmacother. 2014, 48, 209-225. [CrossRef]

256. Jackson, G.M.; Draper, A.; Dyke, K.; Pépés, S.E.; Jackson, S.R. Inhibition, Disinhibition, and the Control of Action in Tourette Syndrome. Trends Cogn. Sci. 2015, 19, 655-665. [CrossRef]

257. Lyseng-Williamson, K.A.; Yang, L.P. Topiramate: A review of its use in the treatment of epilepsy. Drugs 2007, 67, 2231-2256. [CrossRef]

258. Jankovic, J.; Jimenez-Shahed, J.; Brown, L.W. A randomised, double-blind, placebo-controlled study of topiramate in the treatment of Tourette syndrome. J. Neurol. Neurosurg. Psychiatry 2010, 81, 70-73. [CrossRef]

259. Kuo, S.H.; Jimenez-Shahed, J. Topiramate in treatment of tourette syndrome. Clin. Neuropharmacol. 2010, 33, 32-34. [CrossRef] [PubMed]

260. Palma, E.; Ragozzino, D.; Di Angelantonio, S.; Mascia, A.; Maiolino, F.; Manfredi, M.; Cantore, G.; Esposito, V.; Di Gennaro, G.; Quarato, P.; et al. The antiepileptic drug levetiracetam stabilizes the human epileptic GABAA receptors upon repetitive activation. Epilepsia 2007, 48, 1842-1849. [CrossRef]

261. Awaad, Y.; Michon, A.M.; Minarik, S. Use of levetiracetam to treat tics in children and adolescents with Tourette syndrome. Mov. Disord. 2005, 20, 714-718. [CrossRef] [PubMed]

262. Fernández-Jaén, A.; Fernández-Mayoralas, D.M.; Muñoz-Jareño, N.; Calleja-Pérez, B. An open-label, prospective study of levetiracetam in children and adolescents with Tourette syndrome. Eur. J. Paediatr Neurol. 2009, 13, 541-545. [CrossRef]

263. Hedderick, E.F.; Morris, C.M.; Singer, H.S. Double-blind, crossover study of clonidine and levetiracetam in Tourette syndrome. Pediatr. Neurol. 2009, 40, 420-425. [CrossRef] [PubMed]

264. Smith-Hicks, C.L.; Bridges, D.D.; Paynter, N.P.; Singer, H.S. A double blind randomized placebo control trial of levetiracetam in Tourette syndrome. Mov. Disord. 2007, 22, 1764-1770. [CrossRef]

265. Jenner, P.; Pratt, J.A.; Marsden, C.D. Mechanism of action of clonazepam in myoclonus in relation to effects on GABA and 5-HT. Adv. Neurol. 1986, 43, 629-643.

266. Kaim, B. A case of Gilles de la Tourette's syndrome treated with clonazepam. Brain Res. Bull. 1983, 11, 213-214. [CrossRef]

267. Merikangas, J.R.; Merikangas, K.R.; Kopp, U.; Hanin, I. Blood choline and response to clonazepam and haloperidol in Tourette's syndrome. Acta Psychiatry Scand. 1985, 72, 395-399. [CrossRef] [PubMed]

268. Awaad, Y. Tics in Tourette syndrome: New treatment options. J. Child Neurol. 1999, 14, 316-319. [CrossRef]

269. Singer, H.S.; Wendlandt, J.; Krieger, M.; Giuliano, J. Baclofen treatment in Tourette syndrome: A double-blind, placebo-controlled, crossover trial. Neurology 2001, 56, 599-604. [CrossRef]

270. Singer, H.S.; Butler, I.J.; Tune, L.E.; Seifert, W.E., Jr.; Coyle, J.T. Dopaminergic dsyfunction in Tourette syndrome. Ann. Neurol. 1982, 12, 361-366. [CrossRef]

271. Lieberman, J.A., 3rd. Metabolic changes associated with antipsychotic use. Prim. Care Companion J. Clin. Psychiatry 2004, 6 (Suppl. S2), 8-13. [PubMed]

272. Stroup, T.S.; Gray, N. Management of common adverse effects of antipsychotic medications. World Psychiatry 2018, 17, 341-356. [CrossRef]

273. Howell, S.; Yarovova, E.; Khwanda, A.; Rosen, S.D. Cardiovascular effects of psychotic illnesses and antipsychotic therapy. Heart 2019, 105, 1852-1859. [CrossRef] 
274. Stoner, S.C. Management of serious cardiac adverse effects of antipsychotic medications. Ment. Health Clin. 2018, 7, $246-254$. [CrossRef]

275. Widschwendter, C.G.; Hofer, A. Antipsychotic-induced tardive dyskinesia: Update on epidemiology and management. Curr. Opin. Psychiatry 2019, 32, 179-184. [CrossRef]

276. Schooler, N.R.; Kane, J.M. Research diagnoses for tardive dyskinesia. Arch. Gen. Psychiatry 1982, 39, 486-487. [CrossRef]

277. Waln, O.; Jankovic, J. An update on tardive dyskinesia: From phenomenology to treatment. Tremor Other Hyperkinet. Mov. 2013, 3 , tre-03-161-4138-1. [CrossRef]

278. Cornett, E.M.; Novitch, M.; Kaye, A.D.; Kata, V.; Kaye, A.M. Medication-Induced Tardive Dyskinesia: A Review and Update. Ochsner. J. 2017, 17, 162-174. [PubMed]

279. Karaş, H.; Güdük, M.; Saatcioğlu, Ö. Withdrawal-Emergent Dyskinesia and Supersensitivity Psychosis Due to Olanzapine Use. Noro Psikiyatr Ars. 2016, 53, 178-180. [CrossRef] [PubMed]

280. Ricciardi, L.; Pringsheim, T.; Barnes, T.R.E.; Martino, D.; Gardner, D.; Remington, G.; Addington, D.; Morgante, F.; Poole, N.; Carson, A.; et al. Treatment Recommendations for Tardive Dyskinesia. Can. J. Psychiatry 2019, 64, 388-399. [CrossRef]

281. Glazer, W.M.; Morgenstern, H.; Schooler, N.; Berkman, C.S.; Moore, D.C. Predictors of improvement in tardive dyskinesia following discontinuation of neuroleptic medication. Br. J. Psychiatry 1990, 157, 585-592. [CrossRef] [PubMed]

282. Zutshi, D.; Cloud, L.J.; Factor, S.A. Tardive Syndromes are Rarely Reversible after Discontinuing Dopamine Receptor Blocking Agents: Experience from a University-based Movement Disorder Clinic. Tremor Other Hyperkinet. Mov. 2014, 4, 266. [CrossRef]

283. Chapel, J.L.; Brown, N.; Jenkins, R.L. Tourette's disease: Symptomatic relief with haloperidol. Am. J. Psychiatry 1964, 121, 608-610. [CrossRef]

284. Rickards, H.; Hartley, N.; Robertson, M.M. Seignot's paper on the treatment of Tourette's syndrome with haloperidol. Classic Text No. 31. Hist. Psychiatry 1997, 8, 433-436. [CrossRef]

285. Shapiro, A.K.; Shapiro, E.; Wayne, H. Treatment of Tourette's syndrome with haloperidol, review of 34 cases. Arch. Gen. Psychiatry 1973, 28, 92-97. [CrossRef]

286. Ross, M.S.; Moldofsky, H. A comparison of pimozide and haloperidol in the treatment of Gilles de la Tourette's syndrome. Am. J. Psychiatry 1978, 135, 585-587. [CrossRef]

287. Shapiro, E.; Shapiro, A.K.; Fulop, G.; Hubbard, M.; Mandeli, J.; Nordlie, J.; Phillips, R.A. Controlled study of haloperidol, pimozide and placebo for the treatment of Gilles de la Tourette's syndrome. Arch. Gen. Psychiatry 1989, 46, 722-730. [CrossRef]

288. Sallee, F.R.; Nesbitt, L.; Jackson, C.; Sine, L.; Sethuraman, G. Relative efficacy of haloperidol and pimozide in children and adolescents with Tourette's disorder. Am. J. Psychiatry 1997, 154, 1057-1062. [CrossRef]

289. Sandor, P.; Musisi, S.; Moldofsky, H.; Lang, A. Tourette syndrome: A follow-up study. J. Clin. Psychopharmacol. 1990, 10, 197-199. [CrossRef] [PubMed]

290. Budman, C.L. The role of atypical antipsychotics for treatment of Tourette's syndrome: An overview. Drugs 2014, 74, 1177-1193. [CrossRef]

291. Bruggeman, R.; van der Linden, C.; Buitelaar, J.K.; Gericke, G.S.; Hawkridge, S.M.; Temlett, J.A. Risperidone versus pimozide in Tourette's disorder: A comparative double-blind parallel-group study. J. Clin. Psychiatry 2001, 62, 50-56. [CrossRef]

292. Gilbert, D.L.; Batterson, J.R.; Sethuraman, G.; Sallee, F.R. Tic reduction with risperidone versus pimozide in a randomized, double-blind, crossover trial. J. Am. Acad. Child Adolesc. Psychiatry 2004, 43, 206-214. [CrossRef]

293. Regeur, L.; Pakkenberg, B.; Fog, R.; Pakkenberg, H. Clinical features and long-term treatment with pimozide in 65 patients with Gilles de la Tourette's syndrome. J. Neurol. Neurosurg. Psychiatry 1986, 49, 791-795. [CrossRef]

294. Shapiro, A.K.; Shapiro, E.; Eisenkraft, G.J. Treatment of Gilles de la Tourette syndrome with pimozide. Am. J. Psychiatry 1983, 140, 1183-1186. [CrossRef]

295. Tourette Syndrome Study Group. Short-term versus longer term pimozide therapy in Tourette's syndrome: A preliminary study. Neurology 1999, 52, 874-877. [CrossRef] [PubMed]

296. Flockhart, D.A.; Drici, M.D.; Kerbusch, T.; Soukhova, N.; Richard, E.; Pearle, P.L.; Mahal, S.K.; Babb, V.J. Studies on the mechanism of a fatal clarithromycin-pimozide interaction in a patient with Tourette syndrome. J. Clin. Psychopharmacol. 2000, 20, 317-324. [CrossRef] [PubMed]

297. Gulisano, M.; Calì, P.V.; Cavanna, A.E.; Eddy, C.; Rickards, H.; Rizzo, R. Cardiovascular safety of aripiprazole and pimozide in young patients with Tourette syndrome. Neurol. Sci. 2011, 32, 1213-1217. [CrossRef] [PubMed]

298. Shapiro, A.K.; Shapiro, E. Controlled study of pimozide vs. placebo in Tourette's syndrome. J. Am. Acad. Child Psychiatry 1984, 23, 161-173. [CrossRef] [PubMed]

299. Rogers, H.L.; Bhattaram, A.; Zineh, I.; Gobburu, J.; Mathis, M.; Laughren, T.P.; Pacanowski, M. CYP2D6 genotype information to guide pimozide treatment in adult and pediatric patients: Basis for the U.S. Food and Drug Administration's new dosing recommendations. J. Clin. Psychiatry 2012, 73, 1187-1190. [CrossRef] [PubMed]

300. Alderman, J. Coadministration of sertraline with cisapride or pimozide: An open-label, nonrandomized examination of pharmacokinetics and corrected QT intervals in healthy adult volunteers. Clin. Ther. 2005, 27, 1050-1063. [CrossRef]

301. Drolet, B.; Rousseau, G.; Daleau, P.; Cardinal, R.; Simard, C.; Turgeon, J. Pimozide (Orap) prolongs cardiac repolarization by blocking the rapid component of the delayed rectifier potassium current in native cardiac myocytes. J. Cardiovasc. Pharmacol. Ther. 2001, 6, 255-260. [CrossRef] 
302. Shapiro, D.A.; Renock, S.; Arrington, E.; Chiodo, L.A.; Liu, L.X.; Sibley, D.R.; Roth, B.L.; Mailman, R. Aripiprazole, a novel atypical antipsychotic drug with a unique and robust pharmacology. Neuropsychopharmacology 2003, 28, 1400-1411. [CrossRef]

303. Yoo, H.K.; Joung, Y.S.; Lee, J.S.; Song, D.H.; Lee, Y.S.; Kim, J.W.; Kim, B.N.; Cho, S.C. A multicenter, randomized, double-blind, placebo-controlled study of aripiprazole in children and adolescents with Tourette's disorder. J. Clin. Psychiatry 2013, 74, e772-e780. [CrossRef]

304. Cox, J.H.; Seri, S.; Cavanna, A.E. Safety and efficacy of aripiprazole for the treatment of pediatric Tourette syndrome and other chronic tic disorders. Pediatr. Health Med. Ther. 2016, 7, 57-64. [CrossRef]

305. Bruun, R.D.; Budman, C.L. Risperidone as a treatment for Tourette's syndrome. J. Clin. Psychiatry 1996, 57, 29-31. [PubMed]

306. Sandor, P.; Stephens, R.J. Risperidone treatment of aggressive behavior in children with Tourette syndrome. J. Clin. Psychopharmacol. 2000, 20, 710-712. [CrossRef]

307. Scahill, L.; Leckman, J.F.; Schultz, R.T.; Katsovich, L.; Peterson, B.S. A placebo-controlled trial of risperidone in Tourette syndrome. Neurology 2003, 60, 1130-1135. [CrossRef] [PubMed]

308. Gaffney, G.R.; Perry, P.J.; Lund, B.C.; Bever-Stille, K.A.; Arndt, S.; Kuperman, S. Risperidone versus clonidine in the treatment of children and adolescents with Tourette's syndrome. J. Am. Acad. Child Adolesc. Psychiatry 2002, 41, 330-336. [CrossRef] [PubMed]

309. Bymaster, F.P.; Calligaro, D.O.; Falcone, J.F.; Marsh, R.D.; Moore, N.A.; Tye, N.C.; Seeman, P.; Wong, D.T. Radioreceptor binding profile of the atypical antipsychotic olanzapine. Neuropsychopharmacology 1996, 14, 87-96. [CrossRef]

310. Stephens, R.J.; Bassel, C.; Sandor, P. Olanzapine in the treatment of aggression and tics in children with Tourette's syndrome-a pilot study. J. Child Adolesc. Psychopharmacol. 2004, 14, 255-266. [CrossRef] [PubMed]

311. McCracken, J.T.; Suddath, R.; Chang, S.; Thakur, S.; Piacentini, J. Effectiveness and tolerability of open label olanzapine in children and adolescents with Tourette syndrome. J. Child Adolesc. Psychopharmacol. 2008, 18, 501-508. [CrossRef]

312. Huys, D.; Hardenacke, K.; Poppe, P.; Bartsch, C.; Baskin, B.; Kuhn, J. Update on the role of antipsychotics in the treatment of Tourette syndrome. Neuropsychiatr. Dis. Treat. 2012, 8, 95-104. [CrossRef]

313. Sallee, F.R.; Kurlan, R.; Goetz, C.G.; Singer, H.; Scahill, L.; Law, G.; Dittman, V.M.; Chappell, P.B. Ziprasidone treatment of children and adolescents with Tourette's syndrome: A pilot study. J. Am. Acad. Child Adolesc. Psychiatry 2000, 39, 292-299. [CrossRef]

314. Keck, P.E., Jr.; McElroy, S.L.; Arnold, L.M. Ziprasidone: A new atypical antipsychotic. Expert Opin. Pharmacother. 2001, 2, 1033-1042. [CrossRef] [PubMed]

315. Gilbert, D.L.; Murphy, T.K.; Jankovic, J.; Budman, C.L.; Black, K.J.; Kurlan, R.M.; Coffman, K.A.; McCracken, J.T.; Juncos, J.; Grant, J.E.; et al. Ecopipam, a D1 receptor antagonist, for treatment of tourette syndrome in children: A randomized, placebo-controlled crossover study. Mov. Disord. 2018, 33, 1272-1280. [CrossRef]

316. Jankovic, J. Dopamine depleters in the treatment of hyperkinetic movement disorders. Expert Opin. Pharmacother. 2016, 17, 2461-2470. [CrossRef]

317. Kenney, C.J.; Hunter, C.B.; Mejia, N.I.; Jankovic, J. Tetrabenazine in the treatment of Tourette syndrome. J. Pediatr. Neurol. 2007, 5, 9-13.

318. Porta, M.; Sassi, M.; Cavallazzi, M.; Fornari, M.; Brambilla, A.; Servello, D. Tourette's syndrome and role of tetrabenazine: Review and personal experience. Clin. Drug Investig. 2008, 28, 443-459. [CrossRef]

319. Kaur, N.; Kumar, P.; Jamwal, S.; Deshmukh, R.; Gauttam, V. Tetrabenazine: Spotlight on Drug Review. Ann. Neurosci. 2016, 23, 176-185. [CrossRef] [PubMed]

320. Jankovic, J.; Jimenez-Shahed, J.; Budman, C.; Coffey, B.; Murphy, T.; Shprecher, D.; Stamler, D. Deutetrabenazine in Tics Associated with Tourette Syndrome. Tremor Other Hyperkinet. Mov. 2016, 6, 422. [CrossRef]

321. Paton, D.M. Deutetrabenazine: Treatment of hyperkinetic aspects of Huntington's disease, tardive dyskinesia and Tourette syndrome. Drugs Today 2017, 53, 89-102. [CrossRef]

322. Niemann, N.; Jankovic, J. Real-World Experience with VMAT2 Inhibitors. Clin. Neuropharmacol. 2019, 42, 37-41. [CrossRef] [PubMed]

323. Farber, R.H.; Angelov, A.; Kim, K.; Carmack, T.; Thai-Cuarto, D.; Roberts, E. Clinical development of valbenazine for tics associated with Tourette syndrome. Expert Rev. Neurother. 2021, 21, 393-404. [CrossRef]

324. Camargo, C.H.F.; Teive, H.A.G. Use of botulinum toxin for movement disorders. Drugs Context 2019, 8, 212586. [CrossRef]

325. Jankovic, J. Botulinum toxin in clinical practice. J. Neurol. Neurosurg. Psychiatry 2004, 75, 951-957. [CrossRef]

326. Kwak, C.H.; Hanna, P.A.; Jankovic, J. Botulinum toxin in the treatment of tics. Arch. Neurol. 2000, 57, 1190-1193. [CrossRef]

327. Marras, C.; Andrews, D.; Sime, E.; Lang, A.E. Botulinum toxin for simple motor tics: A randomized, double-blind, controlled clinical trial. Neurology 2001, 56, 605-610. [CrossRef] [PubMed]

328. Porta, M.; Maggioni, G.; Ottaviani, F.; Schindler, A. Treatment of phonic tics in patients with Tourette's syndrome using botulinum toxin type A. Neurol. Sci. 2004, 24, 420-423. [CrossRef] [PubMed]

329. Krauss, J.K.; Jankovic, J. Severe motor tics causing cervical myelopathy in Tourette's syndrome. Mov. Disord. 1996, 11, 563-566. [CrossRef] [PubMed]

330. Martinez-Ramirez, D.; Jimenez-Shahed, J.; Leckman, J.F.; Porta, M.; Servello, D.; Meng, F.G.; Kuhn, J.; Huys, D.; Baldermann, J.C.; Foltynie, T.; et al. Efficacy and Safety of Deep Brain Stimulation in Tourette Syndrome: The International Tourette Syndrome Deep Brain Stimulation Public Database and Registry. JAMA Neurol. 2018, 75, 353-359. [CrossRef] [PubMed]

331. Viswanathan, A.; Jimenez-Shahed, J.; Baizabal Carvallo, J.F.; Jankovic, J. Deep brain stimulation for Tourette syndrome: Target selection. Stereotact. Funct. Neurosurg. 2012, 90, 213-224. [CrossRef] [PubMed] 
332. Cheung, M.Y.; Shahed, J.; Jankovic, J. Malignant Tourette syndrome. Mov. Disord. 2007, 22, 1743-1750. [CrossRef]

333. Johnson, K.A.; Fletcher, P.T.; Servello, D.; Bona, A.; Porta, M.; Ostrem, J.L.; Bardinet, E.; Welter, M.L.; Lozano, A.M.; Baldermann, J.C.; et al. Image-based analysis and long-term clinical outcomes of deep brain stimulation for Tourette syndrome: A multisite study. J. Neurol. Neurosurg. Psychiatry 2019, 90, 1078-1090. [CrossRef] [PubMed]

334. Schrock, L.E.; Mink, J.W.; Woods, D.W.; Porta, M.; Servello, D.; Visser-Vandewalle, V.; Silburn, P.A.; Foltynie, T.; Walker, H.C.; Shahed-Jimenez, J.; et al. Tourette syndrome deep brain stimulation: A review and updated recommendations. Mov. Disord. 2015, 30, 448-471. [CrossRef] [PubMed]

335. Smeets, A.Y.J.M.; Duits, A.A.; Leentjens, A.F.G.; Schruers, K.; van Kranen-Mastenbroek, V.; Visser-Vandewalle, V.; Temel, Y.; Ackermans, L. Thalamic Deep Brain Stimulation for Refractory Tourette Syndrome: Clinical Evidence for Increasing Disbalance of Therapeutic Effects and Side Effects at Long-Term Follow-Up. Neuromodulation 2018, 21, 197-202. [CrossRef]

336. Coulombe, M.A.; Elkaim, L.M.; Alotaibi, N.M.; Gorman, D.A.; Weil, A.G.; Fallah, A.; Kalia, S.K.; Lipsman, N.; Lozano, A.M.; Ibrahim, G.M. Deep brain stimulation for Gilles de la Tourette syndrome in children and youth: A meta-analysis with individual participant data. J. Neurosurg. Pediatr. 2018, 23, 236-246. [CrossRef]

337. Kovacs, N.; Herold, R.; Janszky, J.; Komoly, S.; Nagy, F. Tics status: A movement disorder emergency: Observations. J. Neurol. 2011, 258, 143-145. [CrossRef]

338. Robbins, T.W.; Costa, R.M. Habits. Curr. Biol. 2017, 27, R1200-R1206. [CrossRef] [PubMed]

339. Oakley, C.; Mahone, E.M.; Morris-Berry, C.; Kline, T.; Singer, H.S. Primary complex motor stereotypies in older children and adolescents: Clinical features and longitudinal follow-up. Pediatr. Neurol. 2015, 52, 398-403.e1. [CrossRef] [PubMed]

340. Martino, D.; Hedderly, T. Tics and stereotypies: A comparative clinical review. Parkinsonism Relat. Disord. 2019, 59, 117-124. [CrossRef] [PubMed]

341. Freeman, R.D.; Soltanifar, A.; Baer, S. Stereotypic movement disorder: Easily missed. Dev. Med. Child Neurol. 2010, 52, 733-738. [CrossRef] [PubMed]

342. Katherine, M. Stereotypic Movement Disorders. Semin. Pediatr. Neurol. 2018, 25, 19-24. [CrossRef] [PubMed]

343. Specht, M.W.; Mahone, E.M.; Kline, T.; Waranch, R.; Brabson, L.; Thompson, C.B.; Singer, H.S. Efficacy of parent-delivered behavioral therapy for primary complex motor stereotypies. Dev. Med. Child Neurol. 2017, 59, 168-173. [CrossRef]

344. Mulligan, H.F.; Anderson, T.J.; Jones, R.D.; Williams, M.J.; Donaldson, I.M. Tics and developmental stuttering. Parkinsonism Relat. Disord. 2003, 9, 281-289. [CrossRef]

345. Yung, C.Y. Clinical features of movement disorders. Brain Res. Bull. 1983, 11, 167-171. [CrossRef]

346. Kaufmann, C.; Agalawatta, N.; Malhi, G.S. Catatonia: Stereotypies, mannerisms and perseverations. Aust. N. Z. J. Psychiatry 2018, 52, 391-393. [CrossRef] [PubMed]

347. Palumbo, D.; Kurlan, R. Complex obsessive compulsive and impulsive symptoms in Tourette's syndrome. Neuropsychiatr. Dis. Treat. 2007, 3, 687-693.

348. Sanger, T.D.; Chen, D.; Fehlings, D.L.; Hallett, M.; Lang, A.E.; Mink, J.W.; Singer, H.S.; Alter, K.; Ben-Pazi, H.; Butler, E.E.; et al. Definition and classification of hyperkinetic movements in childhood. Mov. Disord. 2010, 25, 1538-1549. [CrossRef]

349. Cardoso, F.; Seppi, K.; Mair, K.J.; Wenning, G.K.; Poewe, W. Seminar on choreas. Lancet Neurol. 2006, 5, 589-602. [CrossRef]

350. Gilbert, D.L. Acute and chronic chorea in childhood. Semin. Pediatr. Neurol. 2009, 16, 71-76. [CrossRef]

351. Geyer, H.L.; Bressman, S.B. The diagnosis of dystonia. Lancet Neurol. 2006, 5, 780-790. [CrossRef]

352. Yanagisawa, N.; Goto, A. Dystonia musculorum deformans. Analysis with electromyography. J. Neurol. Sci. 1971, 13, 39-65. [CrossRef]

353. Ribot, B.; Aupy, J.; Vidailhet, M.; Mazère, J.; Pisani, A.; Bezard, E.; Guehl, D.; Burbaud, P. Dystonia and dopamine: From phenomenology to pathophysiology. Prog. Neurobiol. 2019, 182, 101678. [CrossRef]

354. Mink, J.W. Basal ganglia mechanisms in action selection, plasticity, and dystonia. Eur. J. Paediatr. Neurol. 2018, 22, 225-229. [CrossRef]

355. Mills, K.; Mari, Z. An update and review of the treatment of myoclonus. Curr. Neurol. Neurosci. Rep. 2015, 15, 512. [CrossRef] [PubMed]

356. Faught, E. Clinical presentations and phenomenology of myoclonus. Epilepsia 2003, 44 (Suppl. S11), 7-12. [CrossRef] [PubMed] 